\title{
Schoolverlaters in crisistijd:
}

Citation for published version (APA):

Belfi, B., Allen, J., van Eldert, P., de Grip, A., Künn, A., Peeters, T., \& Poulissen, D. (2018).

Schoolverlaters in crisistijd: Gevolgen voor leren en de vroege loopbaan. ROA. ROA Reports No. 007 https://doi.org/10.26481/umarep.2018007

Document status and date:

Published: 01/01/2018

DOI:

10.26481/umarep.2018007

Document Version:

Publisher's PDF, also known as Version of record

\section{Please check the document version of this publication:}

- A submitted manuscript is the version of the article upon submission and before peer-review. There can be important differences between the submitted version and the official published version of record.

People interested in the research are advised to contact the author for the final version of the publication, or visit the DOI to the publisher's website.

- The final author version and the galley proof are versions of the publication after peer review.

- The final published version features the final layout of the paper including the volume, issue and page numbers.

Link to publication

\footnotetext{
General rights rights.

- You may freely distribute the URL identifying the publication in the public portal. please follow below link for the End User Agreement:

www.umlib.nl/taverne-license

Take down policy

If you believe that this document breaches copyright please contact us at:

repository@maastrichtuniversity.nl

providing details and we will investigate your claim.
}

Copyright and moral rights for the publications made accessible in the public portal are retained by the authors and/or other copyright owners and it is a condition of accessing publications that users recognise and abide by the legal requirements associated with these

- Users may download and print one copy of any publication from the public portal for the purpose of private study or research.

- You may not further distribute the material or use it for any profit-making activity or commercial gain

If the publication is distributed under the terms of Article $25 \mathrm{fa}$ of the Dutch Copyright Act, indicated by the "Taverne" license above, 


\section{Schoolverlaters in crisistijd: Gevolgen voor leren en de vroege loopbaan}

Barbara Belfi

Jim Allen

Peter van Eldert

Andries de Grip

Annemarie Künn-Nelen

Tim Peeters

Davey Poulissen

\section{ROA Rapport}

ROA-R-2018/7

Researchcentrum voor Onderwijs en Arbeidsmarkt | ROA Research Centre for Education and the Labour Market / ROA 


\title{
Colofon
}

(C) Researchcentrum voor Onderwijs en Arbeidsmarkt (ROA). Niets uit deze uitgave mag op enige manier worden verveelvoudigd zonder voorafgaande schriftelijke toestemming van de directeur van het ROA.

\author{
Researchcentrum voor Onderwijs en Arbeidsmarkt \\ Postbus 616 \\ 6200 MD Maastricht \\ $\mathrm{T}+31433883647$ \\ $\mathrm{F}+31433884914$ \\ secretary-roa-sbe@maastrichtuniversity.nl \\ www.roa.nl
}

School of Business and Economics

Maastricht University

\section{Vormgeving}

ROA secretariaat, Maastricht

ISBN: 978-90-5321-583-8

december 2018

\section{NROC)}

Dit rapport maakt onderdeel uit van het NRO project 'Levenslang leren en competentieontwikkeling' (dossiernummer 405-16-402). 


\section{INHOUD}

Resumé

1 inleiding: aanleiding, opzet en verwachtingen

2 In hoeverre worden jongeren geraakt door de crisis? 7

$\begin{array}{ll}2.1 & \text { Ontwikkelingen in arbeidsmarktuitkomsten }\end{array}$

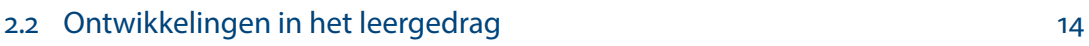

3 Welke invloed heeft een recessieperiode op het leren van schoolverlaters? 19

$\begin{array}{ll}\text { 3.1 Opzet van het onderzoek } & 19\end{array}$

3.2 Volgen van een vervolgopleiding tijdens een hoog- en laagconjunctuur 21

3.3 Studieduurverlenging tijdens een hoog-en laagconjunctuur 23

3.4 Deelname aan bedrijfscursussen- en trainingen tijdens een hoog- en laagconjunctuur 24

$\begin{array}{ll}3.5 & \text { Voor wie zijn de risico's het grootst? }\end{array}$

4 Welke gevolgen heeft het ontbreken van leermogelijkheden voor de vroege loopbaan van schoolverlaters?

4.1 Heeft laagconjunctuur op middellange termijn invloed op arbeidsmarktuitkomsten?

4.2 Middellangetermijneffecten van laagconjunctuur die via doorstroom naar vervolgonderwijs lopen

4.3 Middellangetermijneffecten van laagconjunctuur die via cursusdeelname lopen

4.4 Mediatie-analyse voor de rol van cursusdeelname 


\section{VOORWOORD}

De Nederlandse overheid ervaart het als zeer urgent een goed levenslang leren beleid te ontwikkelen dat onze kenniseconomie een impuls geeft. Daarbij staan twee aan elkaar gerelateerde vragen centraal:

- Over welke competenties moet de (vergrijzende) Nederlandse beroepsbevolking beschikken?

- Hoe kan de scholing en het informeel leren dat daarvoor nodig is worden gestimuleerd?

Het NRO-project Levenslang Leren en competentieontwikkeling (405-16-402) richt zich op het beantwoorden van deze twee vragen in een drietal rapporten en een aanvullend beleidsrapport.

In dit rapport wordt het verband tussen perioden van economische crisis en het leergedrag van pas afgestudeerden mbo'ers en hbo'ers onderzocht. Het leren houdt niet op bij het afronden van het initiële onderwijs. De relatief hoge deelname aan zowel additionele scholing als informele leervormen onder jongeren die nog maar relatief kort zijn afgestudeerd (20-plussers) laat zien dat er juist in de jaren na de school-werk transitie veel geleerd wordt (Kyndt en Baert, 2013). Een verstoring van deze leermogelijkheden kan dus serieuze gevolgen hebben voor de verdere loopbaan. Dit geldt vooral als de overgang naar de arbeidsmarkt en het vroege carrièreverloop tijdens een economische recessie niet zo soepel loopt. In dit rapport wordt onderzocht in hoeverre een recessieperiode van invloed is op het leren door schoolverlaters na het verlaten van het initiële onderwijs, en welke gevolgen eventuele belemmeringen van de leermogelijkheden hebben voor de vroege loopbaan van jongeren. In het rapport zal niet worden ingegaan op de beleidsimplicaties van het onderzoek. Deze zijn te vinden in het samenvattende Beleidsrapport Levenslang leren en competentieontwikkeling van het NRO-project 'Levenslang leren en competentieontwikkeling', waar dit rapport deel van uitmaakt.

Het onderzoek is uitgevoerd op basis van data uit het ROA Schoolverlatersinformatiesysteem (SIS), de HBO-Monitor. Deze data bevatten informatie over de schoolverlaters van het mbo en hbo 1,5 jaar na het behalen van hun diploma. De schoolverlatersdata zijn beschikbaar vanaf begin jaren negentig (ROA 2015), waardoor het effect van met 
name de kredietcrisis in 2008 op de deelname aan post-initiële scholing door schoolverlaters in kaart gebracht kan worden. Deze data zijn aangevuld met gegevens die enkele jaren later verzameld zijn onder dezelfde respondenten. Dit maakt het mogelijk om na te gaan in hoeverre de leermogelijkheden kort na afstuderen het leergedrag en de arbeidsmarktsituatie op iets langere termijn beïnvloeden. In dit rapport wordt daarnaast nog registerdata van het CBS gebruikt.

Wij danken de leden van Klankbordgroep - Dirk Scheele (Ministerie SZW), Ans Harthoorn (Ministerie EZK), André de Moor (Ministerie OCW), Brigid Claassen (SER), Yvonne Bernhardt (SER), Rosanne Zwart (NWO), Pia Hindriks (NWO) en Jonneke Bolhaar (CPB) - voor hun waardevol commentaar op een eerdere versie van dit rapport.

Prof. dr. Andries de Grip

Directeur ROA 


\section{RESUMÉ}

In de afgelopen jaren is reeds heel wat onderzoek uitgevoerd naar de mogelijke negatieve gevolgen van de recente economische crisis voor de kans op werk, het loon en de baanmatch van schoolverlaters. Ook is herhaaldelijk vastgesteld dat jongeren die in tijden van crisis naar de arbeidsmarkt doorstromen het extra zwaar te verduren hebben. Er is echter veel minder bekend over de gevolgen van de recente crisis voor de leermogelijkheden van jongeren, en hoe dit hun verdere carrièreverloop heeft beïnvloed. Dit laatste hebben we in dit rapport nader onderzocht. Onze verwachting was daarbij dat schoolverlaters ander leergedrag vertonen in crisistijd dan in economisch betere tijden, en dat dit hun arbeidsmarktuitkomsten op de middellange termijn beïnvloedt. Dit verwachtten we vanwege twee redenen. Ten eerste hebben bedrijven in tijden van crisis minder geld te besteden, waardoor jonge werknemers die nog maar kort werkzaam zijn minder gelegenheid zouden kunnen krijgen om een cursus te volgen. Vervolgens kan dit een negatieve invloed hebben op hun loopbaanontwikkeling. Ten tweede verwachtten we dat afgestudeerden in tijden van laagconjunctuur er vaker voor kiezen om een vervolgopleiding te volgen, uit vrees om moeilijk een baan te kunnen vinden. Dit zou op langere termijn een positieve invloed kunnen hebben op hun loopbaan. De belangrijkste bevindingen uit dit rapport kunnen als volgt worden samengevat:

\section{Algemene gevolgen van een periode van economische crisis voor jongeren:}

- Jongeren kennen een systematisch hoger werkloosheidspercentage dan ouderen. De werkloosheidspercentages stijgen tijdens of vlak na crisisperioden.

- Het werkloosheidspercentage ligt systematisch hoger onder jongeren met een mbo-niveau 1 diploma. Het werkloosheidspercentage van schoolverlaters van mboniveau 2 en 3 vertoont de sterkste stijging in perioden van laagconjunctuur.

- De toename in het percentage jongeren met een flexibele arbeidsrelatie hangt samen met de flexibilisering van de arbeidsmarkt. De trend lijkt niet tot nauwelijks beïnvloed te zijn geweest door de crisisperiode van 2008-2014.

- De toenemende flexibilisering van de arbeidsmarkt is voor alle onderwijsniveaus zichtbaar. Ook uitgesplitst naar opleidingsniveaus is geen relatie zichtbaar tussen crisis en flexibele arbeidsrelatie.

- Het percentage mbo- en hbo-gediplomeerden dat op het eigen niveau werkt vertoont weinig conjuncturele fluctuatie. 
- Het mediane bruto uurloon lijkt te reageren op de crisis: Voor mbo 2 en 3, mbo 4 en hbo stijgt het uurloon tot 2007, waarna er tot 2013 een daling plaatsvindt.

\section{Gevolgen van een periode van economische crisis op het verder leren van schoolverlaters:}

- Het leergedrag van hbo-gediplomeerden wordt sterker beïnvloed door de laagconjunctuur dan het leergedrag van mbo bol- en mbo bbl-gediplomeerden.

- Zowel mbo- als hbo-diplomeerden nemen in tijden van crisis minder vaak deel aan cursussen. Voor hbo'ers en mbo bol-gediplomeerden is dit negatieve effect het grootst. Wanneer de conjuncturele werkloosheid met $1 \%$ stijgt, nemen ze respectievelijk $1,6 \%$ en $1,5 \%$ minder deel aan cursussen.

- Mbo bol-gediplomeerden volgen in crisistijd vaker een vervolgopleiding, hbo-gediplomeerden juist minder vaak.

- Oorzaken hiervoor zouden kunnen zijn dat het rendement van een vervolgopleiding voor mbo'ers gemiddeld hoger ligt dan voor hbo'ers, en dat het het laatste decennium moelijker én duurder is geworden voor afgestudeerde hbo'ers om door te studeren in het wo (Inspectie van het Onderwijs, 2017; Belfi, e.a. 2017). Daarnaast worden mbo-beroepen vaak harder getroffen tijdens een economische crisis, waardoor de keuze om door te leren relatief aantrekkelijker wordt. De kosten-batenanalyse die gepaard gaat met de keuze tot het al dan niet volgen van een vervolgopleiding valt hierdoor vermoedelijk vaker negatief uit voor hbo-afgestudeerden dan voor mbo-afgestudeerden.

Gevolgen van een economische crisis op het verder leren van schoolverlaters, naargelang hun achtergrondkenmerken:

- Personen met een migratieachtergrond stromen vaker door naar vervolgonderwijs. Een hoge conjuncturele werkloosheid heeft de grootste negatieve invloed op de doorstroom van hbo'ers met een niet-westerse migratieachtergrond.

- Afgestudeerden met een migratieachtergrond maken minder kans op een bedrijfscursus dan autochtonen. Laagconjunctuur vergroot bovendien dit verschil.

- Mannelijke mbo bbl- en hbo-gediplomeerden stromen minder vaak door naar vervolgonderwijs tijdens een laagconjunctuur. Bij mbo bol-gediplomeerden geldt het tegenovergesteld. Vrouwen studeren minder vaak door dan mannen, ongeacht de stand van de conjunctuur.

- Laagconjunctuur leidt vooral bij mannen en in mindere mate ook bij vrouwen tot een verlaging van de cursusdeelname.

- Afgestudeerden met een laag gemiddeld eindcijfer studeren minder vaak door. Laagconjunctuur verlaagt de kans op een vervolgopleiding vooral voor hbo -gediplomeerden met lage eindcijfers.

- Afgestudeerden met een relatief laag eindcijfer volgen minder vaak een cursus, maar het effect van een laagconjunctuur is niet eenduidig naar opleidingsniveau. 
- De doorstroom naar het vervolgonderwijs lijkt voor zowel mbo- als hbo-gediplomeerden geen pad te zijn waarlangs de conjuncturele werkloosheid bij arbeidsmarktintrede invloed heeft op de arbeidsmarktuitkomsten op de middellange termijn.

- De lagere cursusdeelname van hbo'ers tijdens een crisis hangt negatief samen met hun kans op werk op de middellange termijn.

- Cursusdeelname op zowel de korte- als middellange termijn heeft een significant positief effect op de arbeidsmarktuitkomsten op de korte en middellange termijn. Dit biedt perspectief zowel voor gerichte beleid als voor individuele werknemers: door juist meer in scholing te investeren tijdens crisisjaren, kunnen eventuele nadelige effecten op de middellange termijn worden getemperd. 



\section{INLEIDING: AANLEIDING, OPZET EN VERWACHTINGEN}

Het is algemeen bekend dat perioden van economische crisis veel negatieve gevolgen hebben voor de landelijke economie, zoals een sterk stijgende werkloosheid, toenemende armoede, stagnerende lonen, toenemende economische ongelijkheid, lagere belastinginkomsten, hogere staatsschulden en verloren productiviteit (Rose en Spiegel, 2009). Dat jongeren die in tijden van crisis de arbeidsmarkt betreden het extra zwaar te verduren hebben is door verschillende studies aangetoond (Oreopoulos et al., 2012; Kahn, 2010; Verbruggen et al., 2015). Er is echter veel minder bekend over de gevolgen van crisisperioden voor de leermogelijkheden van jongeren, en hoe dit hun verdere carrièreverloop beïnvloedt.

De relatief hoge deelname aan zowel scholing als informele leervormen onder jongeren die nog maar relatief kort zijn afgestudeerd (20-plussers) laat zien dat er juist in de jaren na de school-werk transitie veel geleerd wordt (Fouarge e.a., 2018; Kuenn e.a., 2018; Kyndt \& Baert, 2013). De op school opgedane kennis moet dan immers worden toegepast in de praktijk. Echter, in tijden van economische crisis hebben werkgevers vaak onvoldoende geld voor scholing (Gerards C.S., 2015; Felstead, 2016), en moeten veel schoolverlaters genoegen nemen met een baan onder hun niveau (Liu et al., 2016). Dit zou kunnen betekenen dat jongeren niet alleen tijdens een crisis zelf worden benadeeld, maar ook een leerachterstand oplopen die nadelig kan zijn voor hun latere carrière.

Een economische crisis hoeft overigens niet in alle gevallen nadelig uit te pakken voor de leermogelijkheden voor jongeren. Er is minder reden voor werkgevers om te bezuinigen op minder dure vormen van scholing (Felstead, 2016). Daarnaast zou voor sommige bedrijven (Bosch, 2010) en werknemers een periode van verminderde bedrijvigheid een moment kunnen zijn om te investeren in het menselijk kapitaal van hun medewerkers, opdat het personeel dan productiever zal zijn wanneer de economie weer aantrekt. Ook individuele werknemers kunnen een soortgelijke afweging maken in economisch mindere tijden (Caballero \& Hammour, 1994). Dergelijke investeringsbeslissingen zouden wellicht de algemene tendens om minder in scholing te investeren tijdens een crisis kunnen temperen. 
Scholing in de vorm van cursussen en bedrijfsopleidingen is bovendien niet de enige manier waarop jongeren na afronding van hun studie verder kunnen leren. Zo zijn er indicaties dat jongeren die onzeker zijn over hun kansen op de arbeidsmarkt soms kiezen om hun onderwijsloopbaan te verlengen door nog een tweede (vervolg)studie te volgen (Hershbein, 2012; Guo, 2018). Een dergelijke keuze zou in sommige omstandigheden verstandig kunnen zijn, vooral wanneer de baankansen op korte termijn erg laag zijn. In dat geval zouden de extra kosten die gepaard gaan met het volgen van een extra studie mogelijk te compenseren zijn door het hogere financiële rendement op de langere termijn als gevolg van de verbetering en/of verbreding van de eigen kwalificaties (Hershbein, 2012). Tot slot stellen jongeren in een crisisperiode ook vaker het afronden van hun studie uit (door het volgen van extra vakken en/of stage), in de hoop dat dat de economie weer zal zijn aangetrokken wanneer ze even later de arbeidsmarkt betreden (Chen \& Yur-Austin, 2016; Van den Berge \& Brouwers, 2016).

Om meer zicht te krijgen op hoe een economische crisis de leermogelijkheden van Nederlandse jongeren - en daardoor mogelijk hun arbeidsmarktpositie - precies beïnvloedt, tracht dit rapport de volgende drie onderzoeksvragen te beantwoorden:

1. Welke invloed heeft een periode van economische crisis op het verder leren van schoolverlaters?

2. Beinvloeden economische crises de leermogelijkheden van verschillende groepen schoolverlaters op dezelfde wijze?

3. Welke gevolgen hebben veranderingen van leermogelijkheden tijdens een economische crisis voor de vroege loopbaan van jongeren?

Tot op heden is het verband tussen perioden van economische crisis en het leergedrag van pas afgestudeerden nog maar weinig onderzocht (Felstead, 2016; Bowlus \& Liu, 2003; Herschbein, 2012). Bovendien heeft het weinige onderzoek hiernaar zich op zeer specifieke deelpopulaties en types leergedrag gericht. Zo focuste Felstead (2016) zich met name op de effecten van een economische crisis op de mate waarin bedrijfscursussen werden aangeboden aan Britse werknemers uit de private sector. Herschbein (2012) en Bowlus \& Liu (2003) richtten zich daarentegen op het effect van een economische crisis op de deelname aan vervolgonderwijs van pas afgestudeerde Amerikaanse mannen en vrouwen. Tot op heden is voor zover ons bekend echter nog niet onderzocht in welke mate perioden van economische crisis gepaard gaan met differentieel gedrag van afgestudeerde jongeren met betrekking tot drie typen leergedrag: (1) het volgen van een vervolgstudie, (2) cursusdeelname in het eerste werkjaar, en (3) het uitstellen van het afstudeermoment van de initiële studie. Differentieel leergedrag van jongeren in economisch mindere tijden heeft echter gevolgen voor de accumulatie van hun menselijk kapitaal en arbeidsmobiliteit. Derhalve is het interessant om te onderzoeken in hoeverre dit invloed heeft op bijvoorbeeld hun salaris en arbeidsmarktkansen op middellange termijn. 
Daarnaast is er vooralsnog weinig bekend over de mate waarin perioden van economische crisis samenhangen met het leergedrag van specifieke deelpopulaties. Zo is nog maar zelden onderzocht of het leergedrag van bijvoorbeeld lager opgeleiden, vrouwen en jongeren met een migratieachtergrond op een andere manier wordt beïnvloed door economische crises. Het kan echter belangrijk zijn dit te onderzoeken daar dit zou kunnen betekenen dat de mogelijk compenserende werking van differentieel leergedrag in tijden van laagconjunctuur niet alle deelpopulaties evenredig ten goede zou komen. Derhalve is het mogelijk dat sommige individuen relatief weinig last ondervinden van een hoge werkloosheid bij afstuderen, terwijl voor anderen de nadelige gevolgen hiervan voor de latere beroepsloopbaan veel groter zijn. Door deze differentiële effecten te onderzoeken zouden deelpopulaties kunnen geïdentificeerd worden waarvan het leergedrag kwetsbaar is voor economische mindere tijden.

Tot slot hebben voor zover ons bekend nog maar enkele studies onderzocht hoe het mogelijk differentiële leergedrag van jongeren in economisch mindere tijden samenhangt met hun loopbaanontwikkeling op de middellange termijn. Hebben de mogelijk andere leerkeuzes van jongeren in tijden van economische crisis een langdurige invloed op hun arbeidsloopbaan? Bowlus \& Liu (2003) en Herschbein (2012) onderzochten reeds of het mogelijk verschillende doorstudeergedrag van Amerikaanse jongeren in tijden van economische crisis samenhing met loonverschillen zes jaar naar afstuderen - in vergelijking met jongeren die afstudeerden in economisch betere tijden. Bowlus \& Liu (2003) stelden vast dat blanke afgestudeerden in tijden van economische crisis vaker doorleren, en dat dit een langdurig gunstig effect heeft op hun loon. Voor donkere afgestudeerden kon men echter geen differentieel doorstudeergedrag tijdens crisisperioden identificeren, en derhalve eveneens geen bijkomstig gunstig effect op hun latere loon. Herschbein (2012) kwam verder tot de conclusie dat hoewel mannen - niet vrouwen - vaker een vervolgopleiding afronden in perioden van economische crisis, dit geen blijvend effect had op hun loon zes jaar later. In het voorliggende onderzoek breiden we de studies van Bowlus \& Liu (2003) en Herschbein (2012) uit door zowel de mogelijk mediërende rol van niet één, maar drie types leergedrag te bestuderen (verlengen van de studieduur, deelname aan vervolgonderwijs en cursusdeelname gedurende het eerste werkjaar), de effecten van leergedrag op de loopbaan van zowel lager opgeleiden als hoger opgeleiden te bestuderen, en niet één uitkomstmaat te bestuderen, maar vijf (werkloosheid, type contract, horizontale baanmismatch, bruto uurloon en baantevredenheid).

In de analyses van dit rapport wordt gebruik gemaakt van tijdreeksdata afkomstig van het ROA SchoolverlatersInformatieSysteem (SIS) en de HBO-Monitor. Deze data bevatten informatie over schoolverlaters van het mbo (zowel de beroepsopleidende leerweg (bol) als de beroepsbegeleidende leerweg (bbl)) en het hbo, anderhalf jaar na het behalen van hun diploma. De data zijn beschikbaar vanaf begin jaren negentig (ROA, 2015), waardoor met name het effect van de kredietcrisis van 2008-2009 op de deelname aan post-initiële scholing door schoolverlaters gekwantificeerd kan worden. Dit wordt gedaan door investeringen in vervolgonderwijs en scholing van schoolver- 
laters die vóór de crisis op de arbeidsmarkt instroomden te vergelijken met de investeringen in vervolgonderwijs en scholingsinvesteringen van schoolverlaters die tijdens de crisisjaren op de arbeidsmarkt instroomden. Ook zal worden gekeken hoe mogelijke verschillen in additionele studie-investeringen van cohorten die vóór, tijdens en na de crisis afstudeerden zich verhouden tot de latere baankansen. Bij deze analyses wordt niet alleen gekeken naar de effecten van de crisis op leergedrag in het algemeen, maar ook of deze effecten verschillen naargelang geslacht, etniciteit en gemiddeld afstudeercijfer. Zo kan worden nagegaan of de leermogelijkheden van bepaalde deelpopulaties kwetsbaarder zijn tijdens een economische crisis dan andere.

Deze data worden bovendien aangevuld met gegevens die enkele jaren later zijn verzameld onder dezelfde respondenten. Deze aanvullende data maken het mogelijk om na te gaan hoe leermogelijkheden na de initiële opleiding iemands arbeidsmarktpositie op de middellange termijn (4-8 jaar na afstuderen) beïnvloeden. Hoewel niet valt uit te sluiten dat een eventuele leerachterstand zich op korte termijn reeds in een lager arbeidsmarktrendement vertaalt, is door het relatief korte verblijf op de arbeidsmarkt $(1,5$ jaar $)$ moeilijk hard te maken dat er sprake is van causaliteit. Dit is vooral het geval bij de doorstroom naar vervolgonderwijs: veel afgestudeerden die verder zijn gaan studeren zijn op het moment van de eerste meting (1,5 jaar na afstuderen) immers nog in opleiding. De doorstudeerders die wel al na 1,5 jaar werkzaam zijn, zijn niet alleen een atypische groep, maar hebben ook minder tijd gehad om een baan te vinden en zich daarbinnen te ontwikkelen. Met aanvullende data over dezelfde schoolverlaters enkele jaren na de arbeidsmarktintrede kan zodoende een beter beeld worden geschetst van de relatie tussen leren tijdens een economische crisis en de latere arbeidsmarktpositie. Hoewel de schoolverlaters die na hun initiële studie naar vervolgonderwijs zijn doorgestroomd andere kwalificaties en arbeidsmarktervaring hebben opgedaan, is hier in loopbaanonderzoek goed voor te corrigeren door deze kenmerken als controlevariabelen mee te nemen. Ten slotte maakt de additionele meting het mogelijk om na te gaan of investeringen in iemands scholing kort na het verlaten van de opleiding nog doorwerken op de arbeidsmarktuitkomsten enkele jaren later, ook bijvoorbeeld onder schoolverlaters die inmiddels van werkgever zijn veranderd. Door zowel data te gebruiken van cohorten die vóór, tijdens als na de economische crisis hun opleiding hebben afgesloten, kan inzicht verkregen worden in de specifieke betekenis van het doorleren in crisisjaren.

In 2015 zijn hbo'ers die tijdens de crisis zijn afgestudeerd in het studiejaar 2009/2010 vijf jaar na afstuderen opnieuw bevraagd. Aan de hand van deze tweede bevraging is additionele informatie verkregen over de mogelijke cursus- of trainingsdeelname op het werk en over het volgen van een eventuele formele vervolgstudie. Hierdoor kan worden onderzocht hoe additioneel leergedrag in de eerste jaren na afstuderen samenhangt met iemands arbeidsmarktsituatie ${ }^{5}$ ten tijde van de instroom op de arbeidsmarkt en vijf jaar later. Naast hbo-afgestudeerden uit het studiejaar 2009-2010, zijn ook afge-

5 In dit onderzoek wordt de arbeidsmarktpositie geoperationaliseerd aan de hand van vijf indicatoren (werkloosheid, type contract, horizontale baanmismatch, bruto uurloon en baantevredenheid). 
studeerden de studiejaren 2006/2007, 2008/2009, en 2010/2011 opnieuw bevraagd over hun arbeidssituatie respectievelijk 8, 6 en 4 jaar na afstuderen. Het cohort van 2006/2007 is de arbeidsmarkt opgekomen vóór het begin van de crisis, het cohort van 2008/2009 min of meer gelijktijdig met het begin van de crisis en het cohort van 2010/2011 nadat de crisis al een aantal jaren aan de gang was. Samen met het cohort van 2009/2010 geven deze cohorten dus een goed beeld van de veranderende omstandigheden waaronder hbo'ers de afgelopen jaren de arbeidsmarkt opkwamen. Ook voor SIS heeft een aanvullende bevraging plaatsgevonden. Mbo'ers uit negen afstudeerjaren (2004/2005 t/m 2013/2014) zijn in 2017 opnieuw over hun arbeidsmarktsituatie en leergedrag bevraagd (respectievelijk 4-8 jaar na afstuderen). In tegenstelling tot de additionele bevraging van de HBO-Monitor, is de extra bevraging van SIS specifiek uitgevoerd met het oog op het huidige onderzoek.

In het vervolg van dit rapport wordt in hoofdstuk 2 allereerst een overzicht gegeven van de mate waarin jongeren in het algemeen geraakt worden door de crisis. Hierbij wordt zowel naar verschillende arbeidsmarktuitkomsten - kans op werk, baanzekerheid, aansluiting naar niveau met de gevolgde opleiding, bruto uurloon - gekeken, alsook naar leeruitkomsten: vervolgonderwijs, studieduur en cursusdeelname. Dit hoofdstuk is beschrijvend van aard en geeft slechts een eerste indicatie van een mogelijke relatie tussen crisisjaren tijdens afstuderen en nadelige gevolgen voor leermogelijkheden en de loopbaan van jongeren. Vervolgens wordt in hoofdstuk 3 op basis van de SIS- en HBO-Monitor-data daadwerkelijk onderzocht welke invloed een recessieperiode heeft op het verder leren van schoolverlaters (onderzoeksvraag 1). Hierbij wordt tevens gekeken of de gevolgen van de recente economische crisis voor de leermogelijkheden van jongeren hetzelfde zijn geweest voor verschillende deelpopulaties (onderzoeksvraag 2). Hoofdstuk 4 richt zich tot slot op het analyseren van de gevolgen van veranderingen in de leermogelijkheden tijdens een economische crisis voor de vroege loopbaan van jongeren (onderzoeksvraag 3). 



\section{IN HOEVERRE WORDEN JONGEREN GERAAKT DOOR DE CRISIS?}

Zoals in veel andere landen, is ook in Nederland de economie in een diepe en langdurige recessie verzeild geraakt als gevolg van de kredietcrisis in 2008. Ten tijde van een economische crisis is het ongunstig om de arbeidsmarkt te betreden (Oreopoulos et al., 2012, Kahn., 2010). Bovendien hebben werkgevers in dergelijke perioden vaak onvoldoende geld voor scholing van hun werknemers (Gerards et al., 2015; Felstead, 2016), en moeten veel schoolverlaters genoegen nemen met een baan onder hun niveau (Liu et al., 2016). Hierdoor ligt het voor de hand dat het leergedrag van schoolverlaters die afstuderen in crisistijd achterloopt op dat van schoolverlaters die afstuderen in een hoogconjunctuur. Maar voordat we in dit rapport ingaan op de mogelijke relatie tussen afstuderen in crisistijd en leergedrag, besteden we eerst aandacht aan een breder scala van mogelijke gevolgen van de economische crises voor jongeren.

Om dit in kaart te brengen kijken we in paragraaf 2.1 eerst naar de ontwikkelingen in de arbeidsmarktpositie van pas afgestudeerde mbo- en hbo'ers, en bespreken we deze in relatie tot crisisjaren. Hierbij kijken we naar ontwikkelingen in werkloosheid, flexwerk, werken op niveau, lonen en de conjunctuurgevoeligheid van specifieke opleidingen over verschillende jaren. Er wordt hierbij nog niet gekeken naar significante afwijkingen in waargenomen trends als gevolg van crisisjaren omdat er later in dit rapport meer gedetailleerde analyses uitgevoerd zullen worden. ${ }^{2}$ In paragraaf 2.2 gaan we vervolgens in op de ontwikkelingen in het leergedrag van pas afgestudeerden. Leergedrag omvat daarbij zowel het doorstuderen na de initiële mbo of hbo-opleiding, alsmede de cursusdeelname gedurende het eerste jaar op de arbeidsmarkt. De data waarop dit hoofdstuk is gebaseerd wordt nader toegelicht in bijlage A. ${ }^{3}$

Tot slot onderscheiden we in dit hoofdstuk vijf crisisperioden sinds 1969. Hierbij gaat het allereerst om de oliecrises in 1973 en 1979. Vervolgens vond tussen 2000 en 2002 de dot com crisis plaats, tussen 2008-2009 de kredietcrisis, en gedurende de periode 2009-2014 de Europese staatsschuldencrisis. Deze crisisperioden worden gearceerd weergegeven in de figuren in dit hoofdstuk.

2 Hierbij worden de crisisjaren ook anders gedefinieerd, namelijk gedifferentieerd naar opleidingstype en gebaseerd op werkloosheidscijfers. Zie Hoofdstuk 3 en 4.

3 Zie bijlage $A$. 


\subsection{Ontwikkelingen in arbeidsmarktuitkomsten}

\section{Jeugdwerkloosheid}

Om verschillende redenen komen de gevolgen van een recessie meestal onevenredig hard aan bij nieuwe schoolverlaters. Werkgevers reageren in economisch moeilijke tijden meestal eerst door het verminderen of stopzetten van nieuwe vacatures en pas later eventueel door het ontslaan van zittend personeel. Als er wel vacatures zijn, zullen werkgevers bovendien vaak de voorkeur geven aan ervaren krachten omdat die doorgaans sneller inzetbaar zijn en een kortere inwerktijd nodig hebben dan pas afgestudeerden. Hierdoor kunnen sommige schoolverlaters langdurig werkloos blijven, waardoor hun ervaringsachterstand nog groter wordt.

Figuur 2.1 toont de ontwikkeling van de werkloosheid naar leeftijdsgroep vanaf eind jaren 60.

FIGUUR 2.1 Werkloosheid naar leeftijdsklasse, 1969-2017

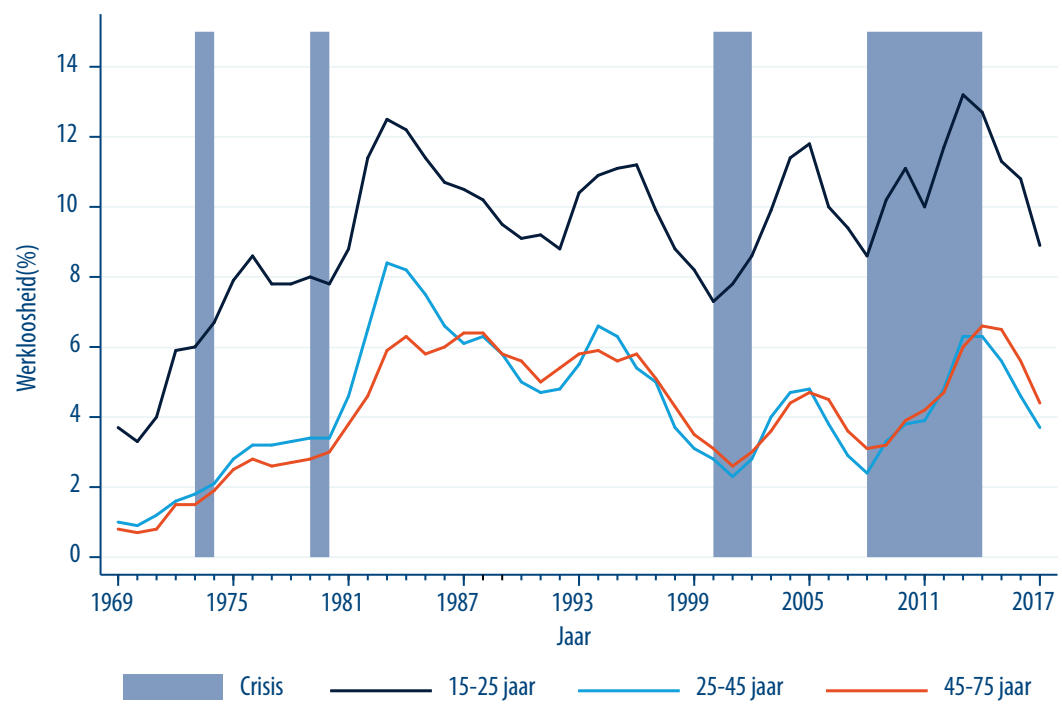

Bron: Statline Arbeidsdeelname, vanaf 1969

Jongeren kennen een systematisch hoger werkloosheidspercentage dan ouderen. De werkloosheidspercentages stijgen tijdens of vlak na crisisperioden.
Uit Figuur 2.1 blijkt allereerst dat het werkloosheidspercentage van jongeren gedurende de hele periode 1969-2017 hoger was dan dat van ouderen. Daarnaast observeren we bij alle leeftijdsgroepen grote werkloos- 
heidsschommelingen. Het is opvallend dat de werkloosheid van alle werkenden ofwel net voor of net na een crisisperiode toeneemt. Echter, met uitzondering van de oliecrisis in 1979, neemt het werkloosheidspercentage van jongeren beduidend meer toe tijdens of na de crises dan dat van ouderen. Op het dieptepunt van de meest recente crisis steeg - voor het eerst sinds 1984 - de jeugdwerkloosheid weer tot boven de 12\%. Uit andere cijfers van het CBS blijkt bovendien dat het daarbij vaak om langdurige werkloosheid gaat: in 2014 was $12 \%$ van alle voor de arbeidsmarkt beschikbare jongeren langer dan 12 maanden werkloos, tegenover $8 \%$ in 2008 . Tot slot toont de grafiek dat de werkloosheid sinds 2014 weer fors is gedaald, en onder jongeren iets sneller dan onder de andere leeftijdsgroepen.

FIGUUR 2.2 Jeugdwerkloosheid naar opleidingsniveau, 2003-2017

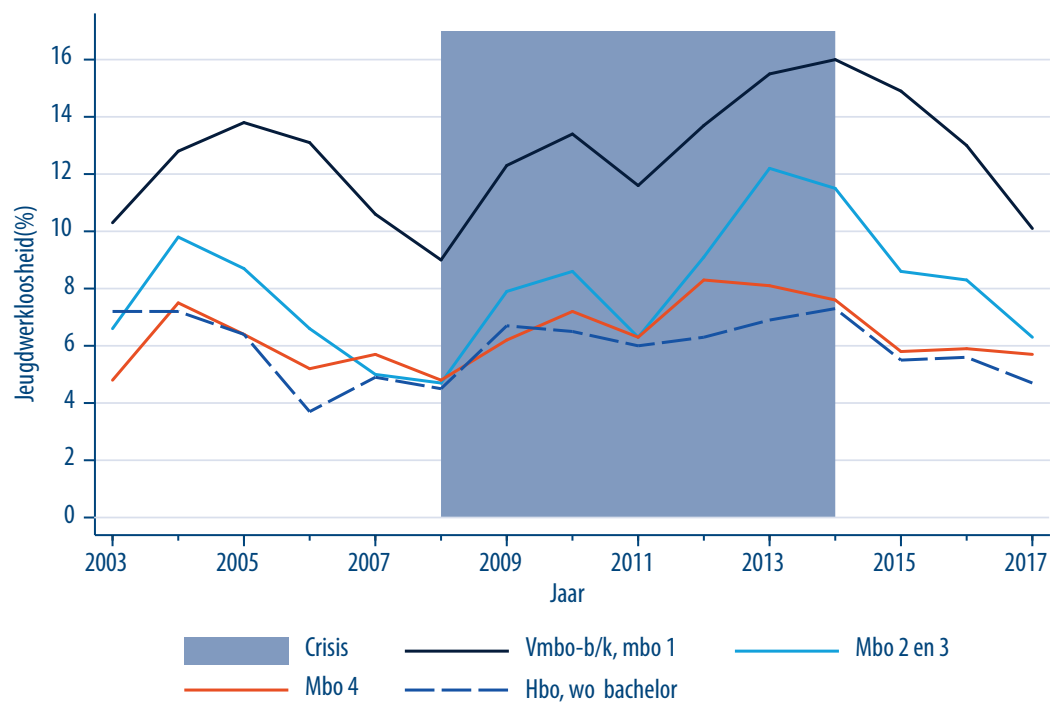

Bron: Statline Arbeidsdeelname; onderwijsniveau

Het werkloosheidspercentage ligt systematisch hoger onder jongeren met een mbo-niveau 1 diploma. Het werkloosheidspercentage van schoolverlaters van mboniveau 2 en 3 vertoont de sterkste stijging in perioden van laagconjunctuur.
Niet alle jongeren worden even zwaar door een crisisperiode getroffen. Figuur 2.2 toont de jeugdwerkloosheid naar opleidingsniveau in de jaren 2003-2017. Uit deze figuur blijkt dat vooral laagopgeleide jongeren getroffen worden door een economische crisis. De toename van de jeugdwerkloosheid tussen 2011 en 2013 was immers het grootste voor jongeren met een vmbo-b/ken mbo $1 / 2 / 3$-opleiding. Maar zelfs in relatief goede jaren kennen laagopgeleiden, met name jongeren met een vmbo-b/k- of mbo 1-opleiding, een beduidend hoger werkloos- 
heidspercentage dan middelbaar- en hoger opgeleiden in dezelfde leeftijdsklasse. Er is daarentegen nauwelijks verschil in werkloosheid tussen jongeren met een mbo 4- en hbo/wo-bachelordiploma. Laagopgeleiden jongeren worden bovendien niet alleen het sterkst door de crises getroffen, maar zij herstellen er ook sneller van. Hierdoor ligt het werkloosheidspercentage van mbo 2/3-gediplomeerden in goede jaren dicht bij het werkloosheidspercentage van mbo 4- en zelfs hbo/wo-bachelor afgestudeerden. Daarnaast is het interessant op te merken dat het herstel na (het inzetten van) een economische crisis niet voor alle opleidingsniveaus tegelijkertijd gebeurt. Zo daalt de jeugdwerkloosheid onder mbo 4-gediplomeerden vanaf 2012, onder mbo 2/3 vanaf 2013 en onder hbo/wo-afgestudeerden pas vanaf 2014.

\section{Flexwerk}

Tijdens crisisperioden zouden werkgevers voorzichtig kunnen zijn met het aanbieden van vaste arbeidscontracten. Flexibele contracten bieden werkgevers namelijk de mogelijkheid om het aantal medewerkers snel te verminderen wanneer er niet genoeg werk meer is. Werkenden hebben tijdens een crisisperiode bovendien weinig onderhandelingsmacht om een vaste aanstelling af te dwingen. Hierdoor zou kunnen verwacht worden het aandeel werkenden met een flexibele arbeidsrelatie toeneemt tijdens een economische crisis. Figuur 2.3 geeft een overzicht van de ontwikkeling in het percentage jongeren (15-25 jaar) met een flexibele arbeidsrelatie in de periode 2003-2017. ${ }^{4}$

De toename in het percentage jongeren met een flexibele arbeidsrelatie hangt samen met de flexibilisering van de arbeidsmarkt. De trend lijkt niet tot nauwelijks beïnvloed te zijn geweest door de crisisperiode van 2008-2014. figuur dat de recente economische crisis geen wezenlijke invloed heeft gehad op deze trend.
Figuur 2.3 laat zien dat het percentage jongere werknemers met een flexibele arbeidsrelatie in de afgelopen 15 jaar gestaag is gestegen van 42 procent in 2003 naar 71 procent in 2017. Dit heeft te maken met de flexibilisering van de arbeidsmarkt (Dekker \& Van der Veen, 2017; Figueiredo et al., 2017). Verder suggereert de

4 Volgens de definitie van het CBS behoren de volgende groepen tot werknemers met een flexibele arbeidsrelatie: (1) werknemers met een tijdelijk contract zonder uitzicht op een vast contract, (2) werknemers met een tijdelijk contract van 1 jaar of langer, (3) werknemers met een tijdelijk contract van korter dan 1 jaar, (4) oproep-/invalkrachten, (5) uitzendkrachten, (6) werknemers met een vast contract maar zonder vaste uren, (7) werknemers met een tijdelijk contract maar zonder vaste uren. 
FIGUUR 2.3 Jongeren met een flexibele arbeidsrelatie, 2003-2017

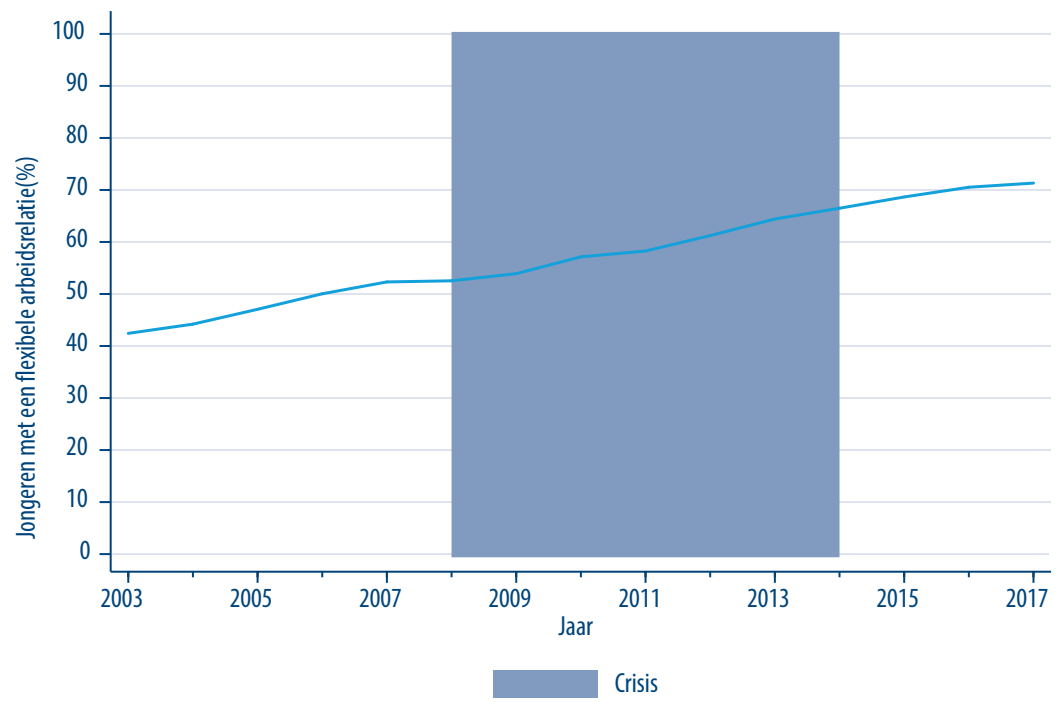

Bron: Statline Arbeidsdeelname; onderwijsniveau

\section{FIGUUR 2.4 Jongeren met een flexibele arbeidsrelatie naar opleidingsniveau, 2003-2017}

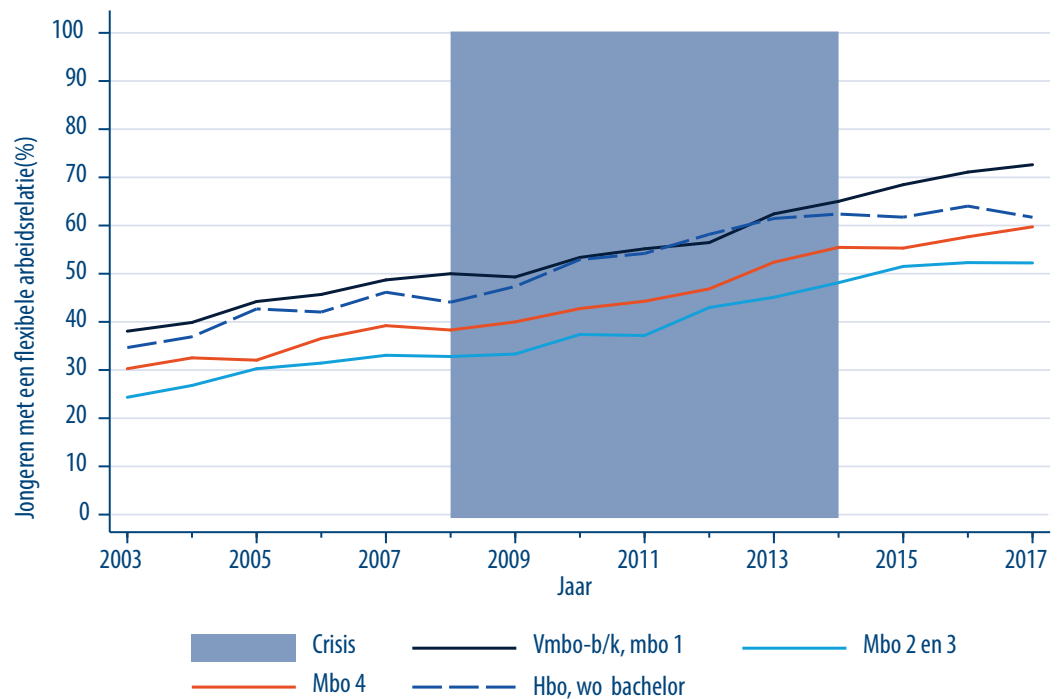

Bron: Statline Arbeidsdeelname; onderwijsniveau 
De toenemende flexibilisering van de arbeidsmarkt is voor alle onderwijsniveaus zichtbaar. Ook uitgesplitst naar opleidingsniveaus is geen relatie zichtbaar tussen crisis en flexibele arbeidsrelatie.
Figuur 2.4 toont een uitsplitsing van het percentage werkenden met een flexibele arbeidsrelatie naar opleidingsniveau. Voor alle opleidingsniveaus is de flexibilisering van de arbeidsmarkt duidelijk waarneembaar: het percentage werkenden met een flexibel

arbeidscontract nam in de periode 2003-2017 voor alle opleidingsniveaus gestaag toe. Voor de groep schoolverlaters van het vmbo-b/k, mbo 1 is het percentage werkenden met een flexibel arbeidscontract het hoogst, en bij de schoolverlaters van mbo $2 / 3$ het laagst. Ook voor de verschillende opleidingsniveaus is echter geen duidelijke relatie zichtbaar tussen de crisisperiode en het percentage jongeren met een flexibele aanstelling.

\section{Werken op niveau}

Door de hogere werkloosheid tijdens een crisisperiode is het vinden van een passende baan dan lastiger dan normaal. Dit zou ervoor kunnen zorgen dat jongeren ten tijde van crisis vaker genoodzaakt zijn een baan onder het eigen niveau aan te nemen. Maar is dat ook zo? Figuur 2.5 toont de ontwikkeling van het percentage werkende schoolverlaters dat een baan op niveau heeft gevonden, verbijzonderd naar opleidingsniveau. Hierbij maken we gebruik van de schoolverlatersdata van het Schoolverlatersonderzoek van het ROA (SIS). ${ }^{5}$ Omdat het schoolverlatersonderzoek onder mbo-gediplomeerden pas vanaf 2003 een representatief beeld geeft, tonen we voor deze groep enkel de cijfers vanaf 2003.

Het percentage mbo- en hbo-gediplomeerden dat op het eigen niveau werkt vertoont weinig conjuncturele fluctuatie.
Uit Figuur 2.5 blijkt dat de fluctuaties in het percentage schoolverlaters dat op het eigen niveau werkzaam is erg klein zijn, vooral sinds 2006. Vanaf dat jaar werkt op

alle opleidingsniveaus meer dan 80 procent van de werkende schoolverlaters op het eigen niveau. Er lijkt geen afname te zijn in het percentage afgestudeerden tijdens of na perioden van economische crisis. 
FIGUUR 2.5 Schoolverlaters die op eigen niveau werken naar opleidingsniveau, 2000-2016

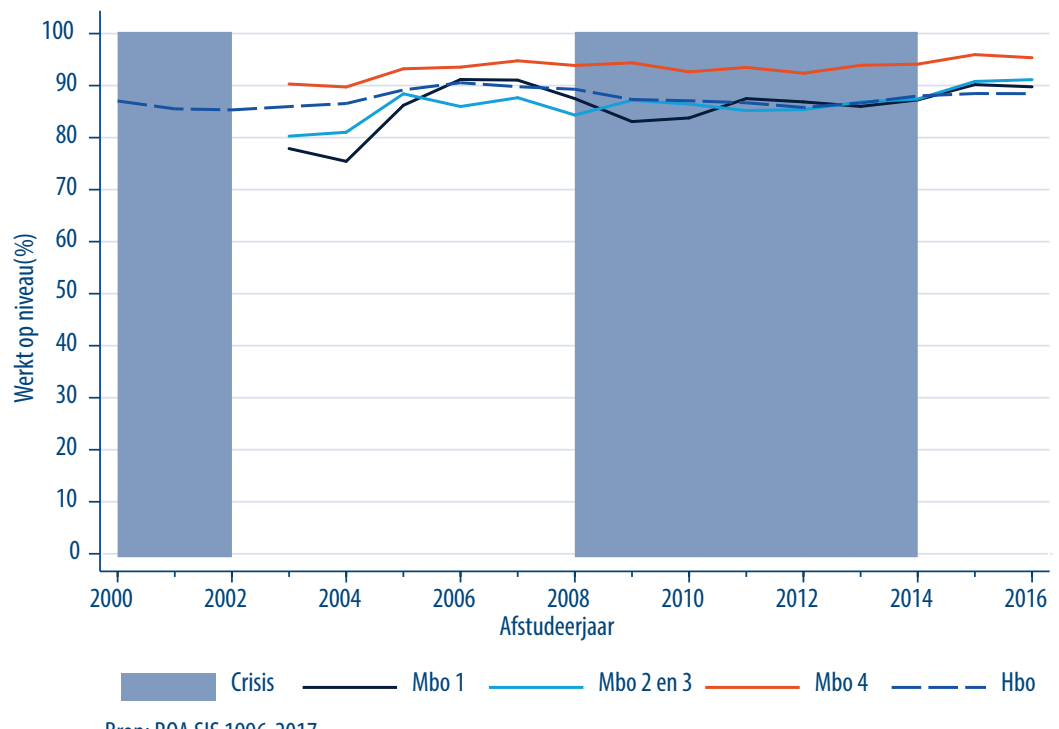

Bron: ROA SIS 1996-2017

\section{Uurloon}

Het is goed mogelijk dat werkzoekenden tijdens laagconjunctuur vanwege het lagere baanaanbod vaker in slechter betaalde banen terechtkomen. Figuur 2.6 toont de ontwikkeling van het niveau en de distributie van het bruto uurloon naar opleidingsniveau in de periode 2001-2016. ${ }^{6}$ Hierbij worden eventuele inkomsten uit nevenfuncties niet meegenomen.

Het mediane bruto uurloon lijkt te reageren op de crisis: Voor mbo 2 en 3 , mbo 4 en hbo stijgt het uurloon tot 2007 , waarna er tot 2013 een daling plaatsvindt.
Figuur 2.6 laat zien dat het bruto uurloon duidelijk verschilt tussen opleidingsniveaus: hoe hoger het opleidingsniveau, hoe hoger het mediane bruto uurloon. Het mediane bruto uurloon is het hoogst voor hbo-afgestudeerden en het laagst voor mbo 1-schoolverlaters. Naast deze niveauverschillen is er ook een golfbeweging te zien. Het mediane bruto uurloon voor mbo 2/3/4 en hbo steeg fors in de periode 2001-2007, maar daalde daarna tot 2013. Na 2013 steeg het mediane bruto uurloon voor deze opleidingsniveaus opnieuw. Deze schommeling is wellicht toe te schrijven aan de gevolgen van de kredietcrisis en de Europese staatsschuldencrisis.

6 Het bruto uurloon is hierbij gecorrigeerd voor inflatie. Omdat informatie over het bruto uurloon in het SIS middels een open vraag verkregen wordt, zijn er voor sommige jaren grote uitbijters aanwezig. Om hiervoor te corrigeren hebben we de verdeling afgetopt op het 99 ste percentiel. 
Voor mbo 1 is het verloop grilliger waardoor er voor dit niveau geen duidelijk golfpatroon waar te nemen is.

FIGUUR 2.6 Ontwikkeling van het niveau en de distributie van het bruto uurloon naar opleidingsniveau, 2001-2016

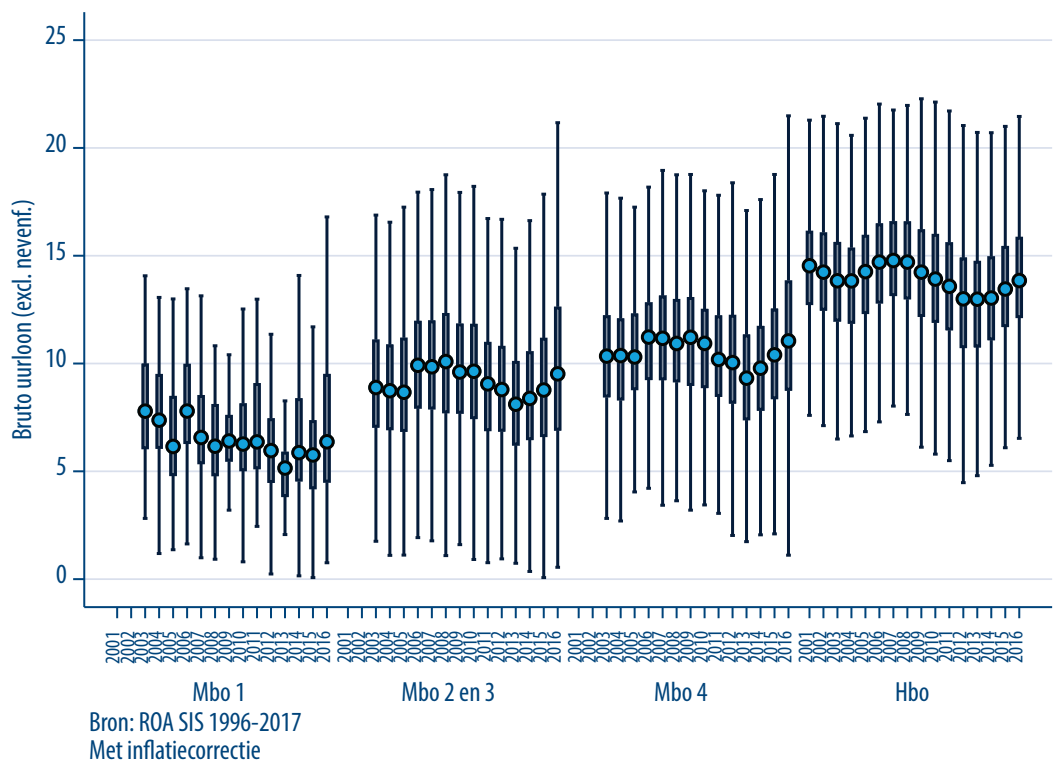

\subsection{Ontwikkelingen in het leergedrag}

Post-initieel leren kan verschillende vormen aannemen, maar in deze paragraaf richten we ons op het doorstuderen en de cursusdeelname. Doorstuderen kan op twee manieren gebeuren. Enerzijds kan iemand doorstuderen door een vervolgopleiding te gaan volgen (op een hoger niveau of in een andere richting), en anderzijds is het mogelijk dat iemand langer over de initiële opleiding gaat doen (door het volgen van extra vakken of stage) om zo nog niet op de arbeidsmarkt in te hoeven stromen. Onder cursusdeelname verstaan we in dit rapport het volgen van een cursus of bedrijfsopleiding na het verlaten van de mbo- of hbo-opleiding (géén hobbycursussen).

\section{Volgen van een vervolgopleiding}

Het volgen van een vervolgopleiding kan voor een betere arbeidsmarktpositie zorgen. De vervolgopleiding kan er immers aan bijdragen dat iemand hoger of breder wordt opgeleid. Dit kan zowel de baankansen als de kwaliteit van de toekomstige baan verhogen. De keuze om door te studeren is een stuk aantrekkelijker bij een ruimere arbeidsmarkt waarin het moeilijker is om een passende baan te vinden dan in een periode van arbeidsmarktkrapte. Daardoor kan verwacht worden dat schoolverlaters 
tijdens een economische crisis vaker een vervolgopleiding zullen volgen. Om hier meer inzicht in te krijgen laten we in Figuur 2.7 de ontwikkeling zien van het percentage schoolverlaters dat na afstuderen kiest om een vervolgopleiding te volgen. Om de analyses in dit rapport niet nog complexer te maken wordt hierbij niet verbijzonderd naar het niveau van de vervolgopleiding. Uit nadere inspectie van de data blijkt namelijk dat het aandeel van de doorstromers dat een vervolgopleiding op hoger, lager of gelijk niveau kiest vrijwel gelijk blijft vóór, tijdens en ná de crisis. Een duidelijke meerderheid kiest voor een vervolgopleiding op hoger niveau, en vrijwel alle andere doorstromers voor een vervolgopleiding op hetzelfde niveau. Omdat deze proporties constant blijven in de tijd, zal een onderscheid naar het niveau van de vervolgopleiding in de analyses derhalve geen noemenswaardige additionele inzichten opleveren.

FIGUUR 2.7 Ontwikkeling van het percentage schoolverlaters dat na afstuderen een vervolgopleiding volgt naar opleidingsniveau, 2000-2016

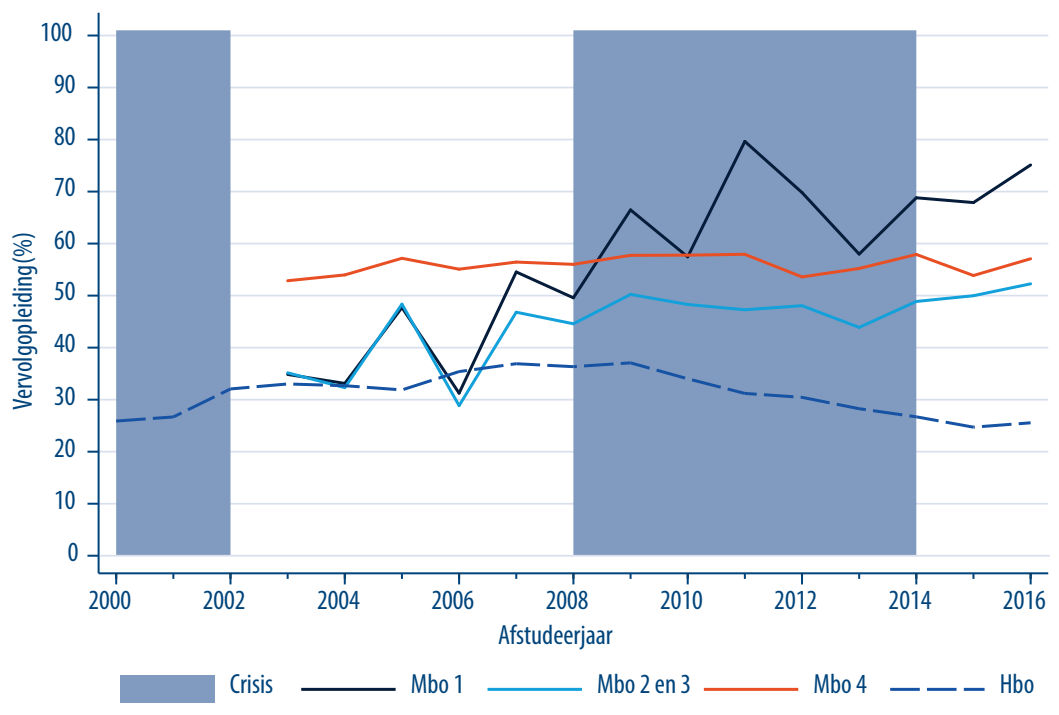

Bron: ROA SIS 1996-2017

Reeds vanaf 2006 is er voor de lagere mbo-niveaus een stijgende trend te zien in de deelname aan vervolgopleidingen, en deze lijkt niet te zijn beïnvloed door de crisis. Op hbo-niveau is de deelname aan vervolgopleidingen vanaf 2009 juist afgenomen.
Figuur 2.7 laat zien dat de ontwikkeling van de deelname aan vervolgopleidingen sterk verschilt naar opleidingsniveau. Het percentage schoolverlaters met een mbo 1-niveau dat kiest voor een vervolgopleiding vertoont een vrij grillig patroon, terwijl er bij de andere opleidingsniveaus sprake is van een meer vloeiende ontwikkeling. Sinds 2006 is onder 
schoolverlaters van zowel mbo 1 als mbo 2 en 3 de deelname aan vervolgopleidingen sterk toegenomen. Onder schoolverlaters van mbo 4 is de deelname aan vervolgopleidingen daarentegen sinds 2003 vrij stabiel rond de 55 procent gebleven. Deze trends onder mbo-gediplomeerden lijken bovendien niet samen te hangen met de crisis omdat ze al voor de crisisperiode van 2008-2014 waren ingezet. Hbo-afgestudeerden volgen het minst vaak een vervolgopleiding. Opvallend is echter dat, in tegenstelling tot mbo-afgestudeerden, de vervolgopleidingsdeelname onder hbo-afgestudeerden sinds 2009, een jaar na het begin van de crisisperiode, aan het afnemen is.

\section{Verlengen van de studieduur}

Een tweede component van leergedrag waar we in dit rapport aandacht aan besteden betreft de keuze om de studieduur van de initiële opleiding te verlengen. Deze keuze hoeft niet noodzakelijk het gevolg te zijn van zwakke studieprestaties, aangezien deze tijd immers ook voor additionele activiteiten kan gebruikt worden, zoals het volgen van extra vakken en/of stages, of het opdoen van buitenlandervaring. Hierdoor kunnen afgestudeerden aantrekkelijker worden op de arbeidsmarkt. Ook wordt hiermee het moment van afstuderen uitgesteld, wat op zichzelf een tactische keuze kan zijn. Afstuderen in crisistijd kan het vinden van een baan immers lastig maken, en als een jaar later de arbeidsmarkt weer aantrekt kunnen deze investeringen de baankansen mogelijk verhogen.

De studieduur van hbo-gediplomeerden lijkt niet samen te hangen met de conjunctuur.

deerden in de jaren 1995-2016. De figuur toont geen duidelijke samenhang tussen de crisisjaren en de gemiddelde studieduur van hbo-afgestudeerden.
Om te kijken of de studieduur varieert naar gelang de stand van de conjunctuur laten we in Figuur 2.8 de ontwikkeling van de gemiddelde studieduur zien van de hbo afgestu-
toont geen duidelijke samenhang tussen de erden.

$\overline{7}$ Voor de mbo-afgestudeerden is deze informatie helaas niet beschikbaar. 
FIGUUR 2.8 Ontwikkeling van de gemiddelde studieduur in jaren voor hbo-afgestudeerden, 19952016

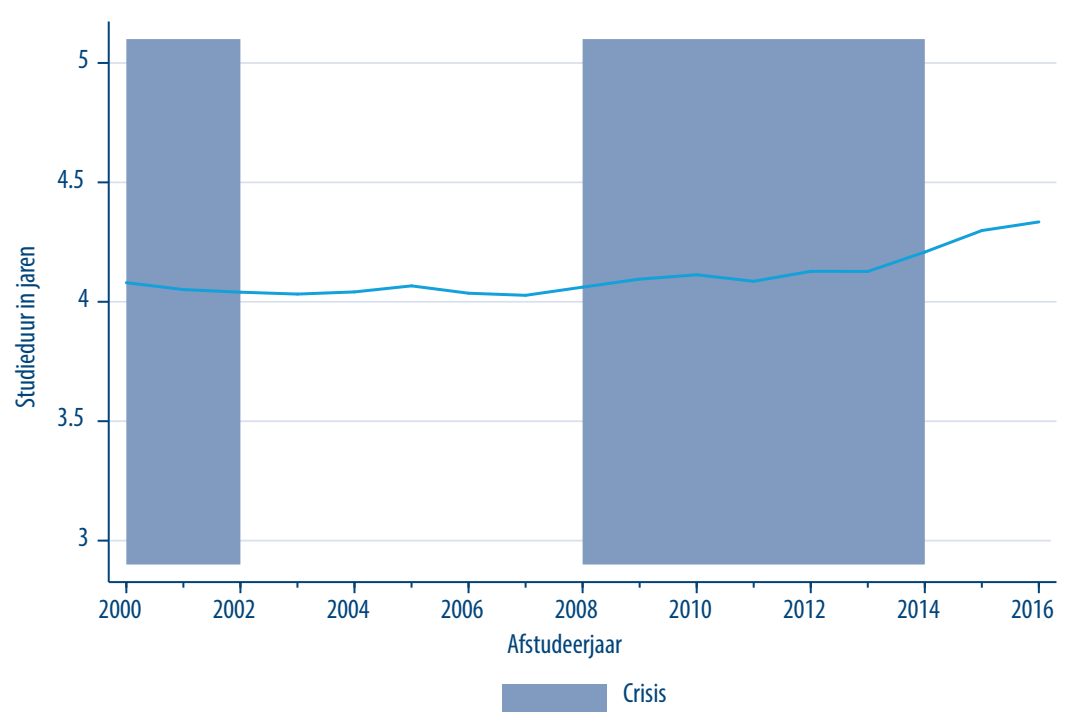

Bron: ROA SIS 1996-2017

\section{Cursusdeelname}

Naast doorstuderen zijn er voor recent afgestudeerden ook binnen hun eerste baan vaak verschillende leermogelijkheden, bijvoorbeeld in de vorm van bedrijfscursussen of -trainingen. Deze cursussen kunnen deel zijn van het inwerkproces bij de nieuwe werkgever, of gericht zijn op het aanvullen van ontbrekende kennis of vaardigheden. Om inzicht te krijgen op de mogelijke gevolgen van een economische crisis op het volgen van cursussen of trainingen laten we in Figuur 2.9 de ontwikkeling zien van de cursusdeelname naar opleidingsniveau. ${ }^{8}$

Het valt niet uit te sluiten dat er een relatie bestaat tussen cursusdeelname en de crisisjaren.
Figuur 2.9 laat zien dat de cursusdeelname onder hbo-afgestudeerden sinds 2006 sterk is gedaald. Bovendien was de cursusdeelname beduidend lager tijdens de crisisperiode dan daarvoor, en lijkt deze onder de mbo 2/3-schoolverlaters de laatste jaren weer omhoog te kruipen. Een eventueel crisiseffect is op basis van deze cijfers dus niet uit te sluiten.

8 Doordat de cursusdeelname niet voor alle niveaus in alle metingen bevraagd is, kunnen we voor de mboopleidingen alleen de ontwikkeling tussen 2006 en 2014 laten zien. Voor de hbo-afgestudeerden is deze informatie beschikbaar voor de jaren 2004 tot en met 2016. 
FIGUUR 2.9 De ontwikkeling van de cursusdeelname naar opleidingsniveau, 2005-2016

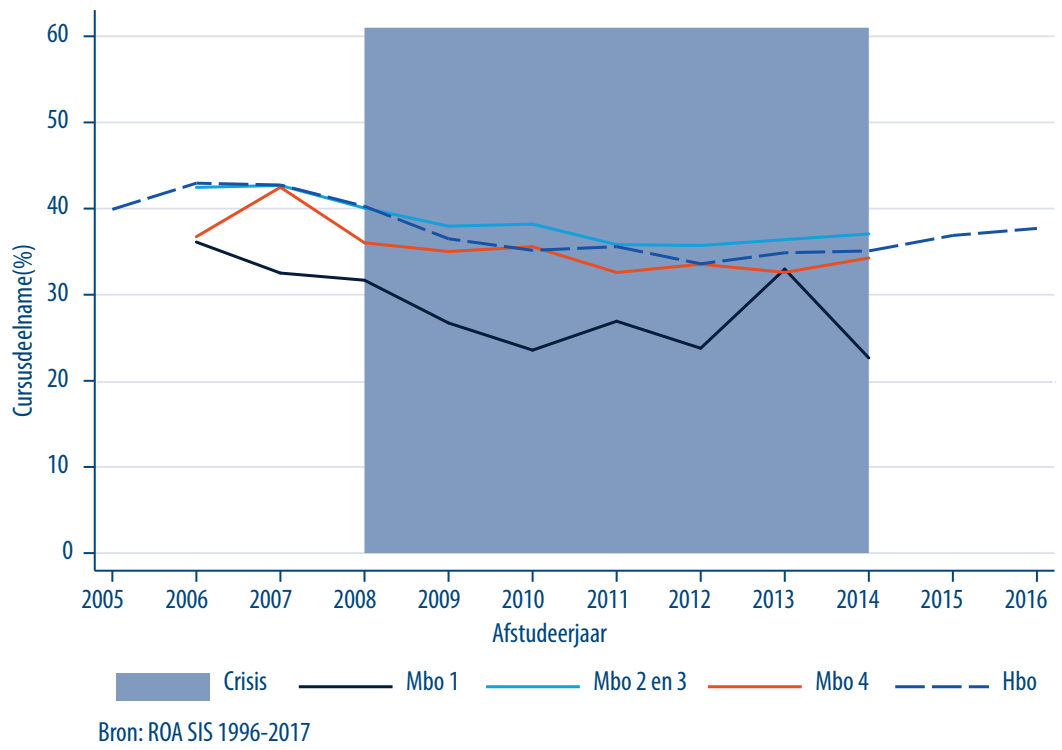

Bron: ROA SIS 1996-2017 


\section{WELKE INVLOED HEEFT EEN RECESSIEPERIODE OP HET LEREN VAN SCHOOLVERLATERS?}

Uit hoofdstuk 2 kwam naar voren dat perioden van economische crisis niet lijken samen te hangen met de gemiddelde studieduur. Wel lijkt er een negatief verband te bestaan tussen crisisperioden en de mate waarin hbo'ers een vervolgopleiding starten of deelnemen aan bedrijfscursussen. Voor mbo'ers was er daarentegen geen duidelijke samenhang te zien tussen crisisperioden en het volgen van een vervolgopleiding. De analyses in hoofdstuk 2 keken echter naar het algehele werkloosheidscijfer. Voor studenten en afgestudeerden is het wellicht relevanter om te kijken naar het werkloosheidspercentage onder gediplomeerden van de eigen opleiding. Daarom kan er meer inzicht verkregen worden in de relatie tussen leergedrag en laagconjunctuur, wanneer er rekening wordt gehouden met werkloosheidsfluctuaties binnen de verschillende mbo- en hbo-opleidingstypes.

Daarbij is het bovendien interessant om de potentiële interactie-effecten met geslacht, migratieachtergrond en het gemiddeld afstudeercijfer te onderzoeken. Burgess et al (2003) vinden bijvoorbeeld dat vrouwen harder getroffen worden door een hoge werkloosheid bij hun arbeidsmarktintrede dan mannen. Dit zou kunnen zorgen voor een sterker crisiseffect op het leergedrag van vrouwen dan op dat van mannen.

De rest van het hoofdstuk is als volgt opgebouwd. Allereest geeft paragraaf 3.1 een korte beschrijving van het multivariate regressiemodel dat we in dit hoofdstuk zullen schatten. Hierbij wordt aandacht besteed aan de manier waarop perioden van laagconjunctuur worden geoperationaliseerd. Paragraaf 3.2 gaat daarna in op de relatie tussen afstuderen in crisistijd en het volgen van een vervolgopleiding, waarna paragraaf 3.3 de relatie tussen afstuderen in crisistijd en het verlengen van de studieduur onderzoekt. Vervolgens focust paragraaf 3.4 op de relatie tussen afstuderen in crisistijd en cursusdeelname. Tot slot kijkt paragraaf 3.5 naar de interactie-effecten met geslacht, migratieachtergrond en gemiddeld eindcijfer met als doel het identificeren van mogelijke kwetsbare groepen.

\subsection{Opzet van het onderzoek}

Het is voor de groep schoolverlaters als geheel niet eenduidig vast te stellen vanaf welk moment ze echt geraakt wordt door een economische crisis. Bij de financiële crisis van 
2008 was het bijvoorbeeld in eerste instantie de financiële sector die het moeilijk kreeg. Pas later had de crisis zichtbare gevolgen voor de rest van de Nederlandse economie. Aangezien sommige bedrijfssectoren eerder werden geraakt dan andere, is het niet mogelijk om een specifiek jaar aan te wijzen waarin de crisis startte voor iedere sector. Bovendien reageert het werkloosheidspercentage anders op crisisperioden naar gelang het opleidingsniveau (zie Figuur 2.2), en zijn per opleidingsniveau niet alle opleidingsrichtingen even conjunctuurgevoelig (zie bijlage B). Gebruik maken van louter nationale of regionale werkloosheidspercentages (zoals Orepoulos et al, 2012; Kahn, 2010) kan daardoor een vertekend beeld geven van de arbeidsmarktkansen van schoolverlaters. Om die reden baseren we onze analyses op jaarlijkse werkloosheidspercentages per opleidingsrichting, welke afkomstig zijn van surveydata uit het SIS. Omdat deze werkloosheidspercentages berekend worden op basis van eerdere cohorten, is er hierbij geen sprake van endogeniteit.

Echter, de werkloosheidsontwikkelingen per opleidingsrichting kunnen een crisisperiode niet altijd goed identificeren. Ook in hoogconjunctuur bestaan er namelijk structurele verschillen tussen de werkloosheidspercentages van de verschillende opleidingsrichtingen. Het is denkbaar dat deze structurele afwijkingen een eigen effect hebben op het leergedrag van studenten en afgestudeerden van de betreffende richtingen. Schoolverlaters van opleidingen met een structureel hoger werkloosheidspercentage zouden immers structureel meer of minder aan leeractiviteiten kunnen ontplooien. Om dit structurele effect op het leergedrag te onderscheiden van het voor dit rapport relevante conjuncturele effect, ontleden we in ons onderzoek het werkloosheidspercentage per opleidingsrichting in een meerjarig gemiddelde - dat het structurele effect van relatief kansrijke versus kansarme opleidingen zal vatten - en een jaarlijkse afwijking - die het cyclische effect van de crisis zal oppakken.

Met deze twee componenten van het werkloosheidspercentage per opleidingsrichting als indicatoren schatten we apart per opleidingsniveau ( $\mathrm{mbo}$ bol, mbo bbl en hbo) een multivariaat regressiemodel voor de drie onderscheiden types van leergedrag: vervolgstudie, studieduurverlening en deelname aan een bedrijfscursus of -training. Omdat er geen reden is om te verwachten dat een economische crisis een systematische effect heeft op de scholingsdeelname van werklozen, worden de resultaten voor cursusdeelname enkel geschat voor werkenden.9,10 Teneinde de interpretatie van de regressieresultaten te bevorderen, zijn de uitkomsten bovendien steeds weergegeven in termen van marginale effecten.

9 De arbeidsmarktstatus van de respondent heeft betrekking op het meetmoment

10 Uit aanvullende analyses blijkt dat de effecten voor werkenden in verzwakte vorm terug te vinden zijn bij werklozen. Dit heeft vermoedelijk te maken met het feit dat een deel van de afgestudeerden die op het moment van de enquête werkloos zijn, wel enige tijd heeft gewerkt sinds afstuderen. 


\subsection{Volgen van een vervolgopleiding tijdens een hoog- en laagconjunctuur}

Personen die afstuderen tijdens laagconjunctuur zouden meer geneigd kunnen zijn om een vervolgopleiding te volgen omdat de opportuniteitskosten om een nieuwe opleiding te starten mogelijk kleiner zijn tijdens perioden met een grotere kans op werkloosheid (van de Berge \& Brouwers, 2016). Het verwerven van meer onderwijs vergroot bovendien hun menselijk kapitaal, wat hun toekomstige baankansen en salaris kan verhogen (Guo, 2018). Daarbij hoeft de keuze om een vervolgopleiding te volgen niet pas na afstuderen gemaakt te worden. Als studenten reeds vóór diplomering merken dat er als gevolg van laagconjunctuur minder werk te vinden is in het eigen vakgebied, zouden ze op dat moment reeds kunnen besluiten om na afstuderen een vervolgstudie te beginnen. Vandaar dat we in de analyses kijken naar de werkloosheid tijdens het jaar van afstuderen, dat deels overlapt met de periode waarin de respondenten nog studeerden. Dit is consistent met onderzoek van bijvoorbeeld Van den Berge en Brouwers (2016), hoewel ons model gebruik maakt van opleidingsspecifieke conjuncturele werkloosheidsafwijkingen.

Om te bepalen of perioden van economische crisis gerelateerd zijn aan de keuze om al dan niet een vervolgopleiding te starten schatten we een logistisch regressiemodel. Daarmee onderzoeken we hoe zowel de conjuncturele als structurele werkloosheid binnen een opleidingstype samenhangt met de kans op het volgen van een vervolgopleiding. Als controlevariabelen worden daarbij steeds geslacht, leeftijd, eindcijfer en etniciteit toegevoegd. Daarnaast controleren we bij de analyses voor hbo-afgestudeerden ook voor hun hoogst behaalde vooropleiding en het aantal jaren dat ze over hun hboopleiding hebben gedaan. ." Deze laatste controlevariabele wordt toegevoegd omdat de drempel om na het behalen van het diploma nog verder te studeren mogelijk hoger kan liggen voor personen die reeds studievertraging hebben opgelopen. De mbo-analyses hebben betrekking op schoolverlaterdata van de afstudeerjaren 2006 tot en met 2016, en de hbo-analyses op schoolverlaterdata van de afstudeerjaren 2002 tot en met 2016.

Tabel 3.1 toont de marginale effecten van de logistische regressies voor de relatie tussen de kans op het volgen van een vervolgstudie en zowel het meerjarig gemiddeld werkloosheidpercentage als de afwijking hiervan een jaar voor afstuderen. Deze marginale effecten zijn vermenigvuldigd met 100 zodat ze kunnen geïnterpreteerd worden als procentuele wijzigingen in de kans om een vervolgopleiding te volgen wanneer de structurele of conjuncturele werkloosheid met één procentpunt wijzigt.

Uit de tabel blijkt dat een toename van het conjuncturele werkloosheidspercentage met 1 procentpunt zorgt voor een toename in de kans dat mbo bol-gediplomeerden een vervolgopleiding volgen met gemiddeld 0,3 procentpunten. Voor een opleiding waarvan de conjuncturele werkloosheid stijgt van $3 \%$ naar $8 \%$, zal de doorstroom naar vervolgonderwijs naar verwachting dus met 1,5 procentpunten toenemen. Dit is een aanzienlijke stijging, al betreft het een relatief kleine groep mensen.

11 Voor de mbo-schoolverlaters is deze laatste informatie niet beschikbaar. 
Mbo bol-gediplomeerden beginnen vaker een vervolgopleiding in perioden van economische crisis. Hbo-gediplomeerden volgen in crisisperioden daarentegen minder vaak een vervolgopleiding.

Bij hbo-gediplomeerden zorgt eenzelfde conjuncturele werkloosheidstoename van 5 procentpunten echter voor een afname van de kans om een vervolgopleiding te volgen met 3 procentpunten. Dit is consistent met Figuur 2.8, die een daling van het doorstu-
de meest recente economische crisis. Deze deergedrag van hbo'ers liet zien tijdens de meest recente economische crisis. Deze
uitkomst is daarentegen niet consistent met Van den Berge en Brouwers (2016), die geen statistisch significante relatie vonden tussen een hoge werkloosheid bij afstuderen en de mate waarin hbo'ers een vervolgopleiding beginnen. Dit zou echter verklaard kunnen worden doordat Van den Berge en Brouwers gebruik maken van nationale in plaats van opleidingsspecifieke werkloosheidspercentages.

De bevinding dat afgestudeerde hbo'ers - anders dan mbo bol-gediplomeerden minder vaak een vervolgopleiding starten als gevolg van een hogere conjuncturele werkloosheid, zou kunnen verklaard worden doordat extra onderwijs typisch gepaard gaat met dalende meeropbrengsten (Psacharopoulos \& Patrinos, 2002), en doordat de nominale kosten van onderwijs doorgaans stijgen met het opleidingsniveau en niet mee variëren met de conjunctuur. Dit maakt dat de kosten-baten afweging van hbo'ers om een vervolgopleiding te volgen vermoedelijk vaker negatief uitvalt wanneer zij geconfronteerd worden met een periode van relatief hoge conjuncturele werkloosheid. De kosten-baten afweging van mbo'ers zal in deze gedachtegang daarentegen vaker positief zijn, temeer omdat lager opgeleiden typisch harder door een crisisperiode worden getroffen, waardoor de nood voor bijkomende onderwijskwalificaties toeneemt (Speer, 2015; Wolbers, 2014). Gegeven de hogere nominale onderwijskosten van hoger onderwijs in vergelijking met middelbaar onderwijs, zal de fractie van het inkomen dat besteed moet worden aan hoger onderwijs bovendien sterker stijgen als gevolg van een daling van het inkomen tijdens een economische crisis, wat de keuze voor een hogere vervolgopleiding sterker kan ontmoedigen.

Ten slotte blijkt dat afgestudeerden van mbo bol- en hbo-opleidingen met structureel zwakkere arbeidsmarktperspectieven vaker doorstromen naar vervolgonderwijs. Gediplomeerden van mbo bbl volgen daarentegen significant minder vaak een vervolgopleiding wanneer de structurele werkloosheid binnen hun opleiding hoger is. Dit laatste zou terug te voeren kunnen zijn naar een mogelijk gebrek aan opleidingsplaatsen voor bbl'ers die willen doorstromen naar een vervolgopleiding (veelal een hoger mbo bbl-niveau) in tijden van economische crisis. 
TABEL 3.1 Relatie tussen de kans op het volgen van een vervolgopleiding en werkloosheid in het jaar van afstuderen

\begin{tabular}{|lccc|}
\hline Werkloosheid in het jaar van afstuderen & Mbo bol & Mbo bbl & Hbo \\
\hline - conjuncturele werkloosheid & & & \\
\hline - structurele werkloosheid & $0,30^{* * *}$ & $-0,30$ & $-0,60^{* * *}$ \\
\hline N & $0,40^{* * *}$ & $-2,50^{* * *}$ & $0,30^{* * *}$ \\
\hline$* * *$ & & \\
\hline
\end{tabular}

Bron: SIS ROA, 2003-2017

Bij de mbo-analyses werd gecontroleerd voor geslacht, leeftijd, etniciteit en eindcijfer. Bij de hboanalyses werd daarnaast ook gecontroleerd voor de hoogst voltooide vooropleiding en de bruto studieduur.

\subsection{Studieduurverlenging tijdens een hoog-en laagconjunctuur}

De mogelijk lagere opportuniteitskosten om een bijkomende opleiding te volgen tijdens laagconjunctuur gelden eveneens voor het verlengen van de studieduur. Ook door langer over de initiële opleiding te doen kunnen studenten immers trachten te voorkomen dat ze de arbeidsmarkt betreden in tijden waarin ze minder kans maken om een baan te bemachtigen. In de literatuur is over het bestaan van dit mechanisme echter geen eensgezindheid. Terwijl Guo (2018) vindt dat studenten meer geneigd zijn langer te studeren tijdens een recessieperiode, kunnen Van den Berge en Brouwers (2016) dit niet aantonen voor perioden van hoge werkloosheid. In tegenstelling tot onze analyses maken deze studies echter geen gebruik van opleidingsspecifieke werkloosheidscijfers.

Met behulp van OLS schatten we de relatie tussen opleidingsspecifieke afwijkingen van het meerjarige werkloosheidsgemiddelde op de studieduur van gediplomeerde hbo'ers uit de afstudeerjaren 2002 tot 2016. ${ }^{12}$ Daarbij betreft het opnieuw werkloosheidspercentages uit het jaar van afstuderen, ${ }^{13}$ en controleren we voor dezelfde achtergrondkenmerken als bij vervolgopleiding.

Tabel 3.2 toont de regressieresultaten voor de relatie tussen laagconjunctuur en de duur van de studie. In lijn met Guo (2018) vinden we dat periodes van laagconjunctuur significant positief samenhangen met de gemiddelde studieduur van hbo'ers. Wanneer de opleidingsspecifieke conjuncturele werkloosheid van hbo-gediplomeerden met 1

12 Voor mbo'ers kunnen deze analyses niet uitgevoerd worden wegens een gebrek aan mbo-data over studieduurverlening.

13 Uit robuustheidschecks blijkt dat de effecten niet veel verschillen wanneer we de situatie drie jaar voor het meetmoment of de situatie op het meetmoment zelf als uitgangspunt nemen. 
procentpunt toeneemt, dan stijgt hun gemiddelde studieduur met ongeveer 0,13 jaar. Bij een stijging van de conjuncturele werkloosheid met 5 procentpunten komt dit neer op een studieduurverlening van gemiddeld bijna 8 maanden.

TABEL 3.2 Relatie tussen studieduur en werkloosheid in het jaar van afstuderen

\begin{tabular}{lc|}
\hline Werkloosheid in het jaar van afstuderen & Hbo-gediplomeerden \\
\hline - conjuncturele werkloosheid & $0,13^{* * *}$ \\
\hline - structurele werkloosheid & $0,30^{* * *}$ \\
\hline N & 174.035 \\
\hline B** $p<0.01,{ }^{* *} p<0.05,{ }^{*} p<0.1$ & \\
Gecontroleerd voor geslacht, leeftijd, etniciteit, eindcijfer en de hoogst voltooide vooropleiding.
\end{tabular}

\subsection{Deelname aan bedrijfscursussen- en trainingen tijdens een hoog- en laagconjunctuur}

Tot slot focussen we ons op de mogelijke relatie tussen perioden van economische crisis en de kans dat mbo'ers en hbo'ers aan een bedrijfscursus of -training deelnemen. Laagconjunctuur zou namelijk gepaard kunnen met een lagere cursusdeelname omdat bedrijven in economisch mindere
De cursusdeelname van schoolverlaters is lager in tijden van economische crisis dan bij economische voorspoed. De cursusdeelname van hbo'ers wordt het sterkst verstoort door de crisis, en de cursusdeelname van mbo bol'er het minst. tijden meer geneigd zouden kunnen zijn hierop te besparen. De uitkomsten worden geschat met behulp van logistische regressie, en zijn gecontroleerd voor dezelfde achtergrondkenmerken als bij de twee andere leervormen. Ook hier worden de analyses gebaseerd op de conjuncturele afwijking van het meerjarig opleidingsspecifieke werkloosheidspercentage in het jaar van afstuderen. Voor mbo-schoolverlaters zijn data beschikbaar voor de afstudeerjaren 2006 tot en met 2014, en voor hbo-schoolverlaters voor de afstudeerjaren 2002 tot en met 2016.

Tabel 3.3 toont de resultaten voor de relatie tussen laagconjunctuur en de kans op cursusdeelname. Deze zijn, net als bij vervolgopleiding, weergegeven in termen van marginale effecten. Gediplomeerden van alle drie de onderscheiden opleidingsniveaus hebben een significant kleinere kans om een bedrijfscursus of -opleiding te volgen in tijden van economische crisis. Het grootste effect geldt daarbij voor hbo'ers en mbo bbl-gediplomeerden, die gemiddeld respectievelijk 1,6\% en 1,5\% minder kans hebben om een cursus te volgen wanneer de conjuncturele werkloosheid met 1 procentpunt 
toeneemt. ${ }^{14}$ Verder valt op dat er minder geïnvesteerd wordt in afgestudeerden van opleidingen met een relatief hoge structurele werkloosheid. Het negatieve effect van conjuncturele werkloosheid komt hier vermoedelijk bovenop, zodat deze schoolverlaters dubbel worden getroffen.

TABEL 3.3 Relatie tussen cursusdeelname van werkenden en werkloosheid in het jaar van afstuderen

\begin{tabular}{|c|c|c|c|}
\hline & Mbo bol & Mbo bbl & Hbo \\
\hline \multicolumn{4}{|c|}{ Werkloosheid in het jaar van afstuderen } \\
\hline - conjuncturele werkloosheid & $-1,20^{* * *}$ & $-1,50^{* *}$ & $-1,60^{* * *}$ \\
\hline - structurele werkloosheid & $-1,80^{* * *}$ & $-5,90^{* * *}$ & $-2,00^{* * *}$ \\
\hline N & 21,863 & 8,653 & 135,754 \\
\hline
\end{tabular}

Bron: SIS ROA, 2008-2017

Bij de mbo-analyses werd gecontroleerd voor geslacht, leeftijd, etniciteit en eindcijfer. Bij de hboanalyses werd daarnaast ook gecontroleerd voor de hoogst voltooide vooropleiding.

Een economische crisis kan eveneens tot gevolg hebben dat baanzoekende schoolverlaters genoegen moeten nemen met een baan met slechtere arbeidsvoorwaarden, bijvoorbeeld omdat ze vaker een tijdelijk contract in plaats van een vast contract krijgen aangeboden, een lager loon moeten accepteren of genoegen moeten nemen met een baan buiten hun richting of niveau. Deze slechtere arbeidsvoorwaarden kunnen ook weer een effect hebben op de mate waarin deze schoolverlaters cursussen of trainingen volgen. Uit aanvullende analyses (hier niet getoond) blijkt dat ongeveer de helft van het negatieve effect van laagconjunctuur op het volgen van een cursus of training toe te schrijven is aan de lagere kwaliteit van de startbanen van schoolverlaters in termen van contracttype, horizontale mismatch en uurloon. Het resterend effect - dat na controle voor baankenmerken maar nog steeds significant negatief blijft - is dus een algemeen effect van de crisis op scholingsinvesteringen in alle typen banen.

\subsection{Voor wie zijn de risico's het grootst?}

De resultaten uit de vorige paragraaf suggereren dat mbo- en hbo-gediplomeerden hun leergedrag aanpassen tijdens perioden van economische crisis. Mbo'ers gaan vaker een vervolgopleiding volgen en nemen minder deel aan bedrijfscursussen en -trai-

14 De bevinding dat cursusdeelname daalt tijdens een economische crisis wijkt af van de resultaten van Felstead, Green en Jewson (2012), die nauwelijks een effect vonden van de recessie van 2008-2009 op de trainingsparticipatie in het Verenigd Koninkrijk. 
ningen. Hbo'ers beginnen daarentegen tijdens laagconjunctuur minder frequent met een vervolgopleiding, maar verlengen wel vaker hun studieduur ${ }^{15}$ en nemen eveneens minder deel aan bedrijfscursussen. De effecten in de voorgaande analyses lieten echter niet toe om te kijken of het leergedrag van specifieke groepen anders reageert op crisisjaren. Door de toevoeging van interacties met geslacht, migratieachtergrond en gemiddeld eindcijfer trachten we daarom in deze paragraaf mogelijke kwetsbare groepen met betrekking tot leergedrag in crisistijd te identificeren. De hoofdeffecten en interactietermen geven dan samen een beeld van de impact van bepaalde achtergrond- of opleidingskenmerken op het leergedrag kort na het verlaten van de initiële opleiding, en van de mate waarin deze effecten verschillen in perioden van relatief hoge versus relatief lage werkloosheid ten opzichte van het meerjarig gemiddelde.

Figuur 3.1 geeft weer in welke mate de keuze om een vervolgopleiding te volgen als gevolg van conjuncturele werkloosheid verschilt tussen mannen en vrouwen. Binnen elk opleidingsniveau zijn de cijfers te interpreteren als procentuele wijzigingen in de kans op doorstroom naar vervolgonderwijs in tijden van relatief hoge of relatief lage conjuncturele werkloosheid ten opzichte van vrouwen met een gemiddelde werkloosheid (de referentiecategorie).

Mannelijke mbo bbl- en hbo-gediplomeerden stromen minder vaak door naar vervolgonderwijs tijdens een periode van laagconjunctuur. Bij mbo bol-gediplomeerden geldt het tegenovergestelde. Vrouwen studeren minder vaak door dan mannen, ongeacht de stand van de conjunctuur.
Ondanks dat vrouwen gemiddeld harder worden getroffen door een hoge werkloosheid bij arbeidsmarktintrede (Wolbers, 2014; Burges et al, 2013), kan met betrekking tot de conjuncturele effecten gesteld worden dat het vooral de mannen zijn die zich bij hun keuze om door te stromen naar een vervolgopleiding door de stand van de conjunctuur laten beïnvloeden. Dit geldt vooral voor mannelijke afgestudeerden van het hbo en mbo bbl. Bij deze groep neemt de doorstroom naar vervolgonderwijs sterk af bij een hoge conjuncturele werkloosheid. Bij het mbo-bol blijken mannen juist iets vaker voor vervolgonderwijs te kiezen tijdens een periode van laagconjunctuur. Over de gehele linie blijken vrouwen beduidend minder vaak voor vervolgonderwijs te kiezen dan mannen, en zich hierbij nauwelijks te laten beïnvloeden door de stand van de conjunctuur.

15 Aangezien in de analyses voor vervolgonderwijs werd gecontroleerd voor studieduur kunnen deze effecten als onafhankelijk worden beschouwd. 
FIGUUR 3.1 Man-vrouw verschillen in de keuze voor een vervolgopleiding bij hoge en lage werkloosheid

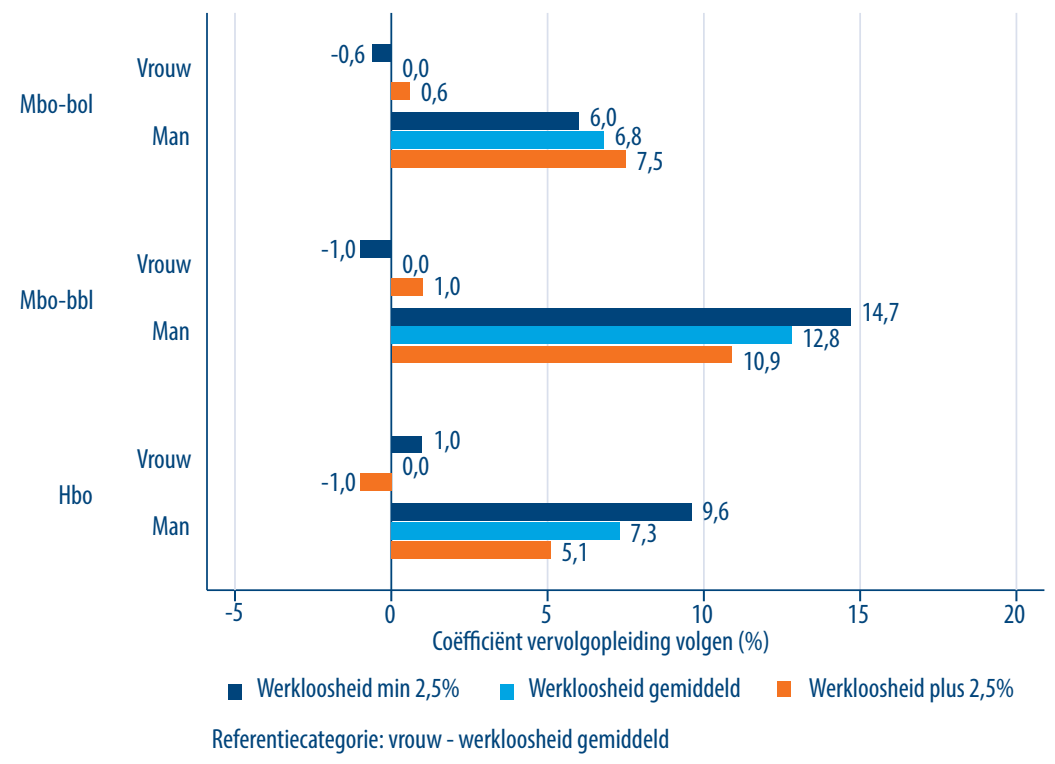

Interactie tussen geslacht en conjuncturele werkloosheid significant op 1\% niveau voor alle opleidingsniveaus

Bron: SIS ROA, 2003-2017

Personen met een migratieachtergrond stromen vaker door naar vervolgonderwijs. Een hoge conjuncturele werkloosheid heeft de grootste negatieve invloed op de doorstroom naar vervolgonderwijs van hbo'ers met een niet-westerse migratieachtergrond.
De effecten van etniciteit op de kans om door te stromen naar vervolgonderwijs zijn weergegeven in Figuur 3.2. In het algemeen kan gesteld worden dat personen met een migratieachtergrond een grotere kans hebben om een vervolgopleiding te volgen dan autochtonen. In het bijzonder geldt dit voor personen met een niet-westerse migra-

tieachtergrond. Dit zou verklaard kunnen worden doordat etnische minderheden vaker een moeilijke arbeidsmarktintrede verwachten (Luzzo \& McWhirter, 2001). Als gevolg daarvan zouden ze kunnen trachten hun arbeidsmarktkansen te vergroten door een hoger onderwijsniveau te bereiken.

Laagconjunctuur lijkt een negatieve invloed te hebben op de kans dat hbo-gediplomeerden met een niet-westerse migratieachtergrond een vervolgopleiding starten. Een conjuncturele werkloosheid die 2,5 procentpunten hoger is dan gemiddeld verkleint namelijk hun kans op een vervolgopleiding met bijna 4 procentpunten. Bij mbo-bol en mbo-bbl zijn de interacties tussen etniciteit en conjuncturele werkloosheid niet significant. 
FIGUUR 3.2 Relatie tussen etniciteit en de keuze voor een vervolgopleiding bij hoge en lage werkloosheid

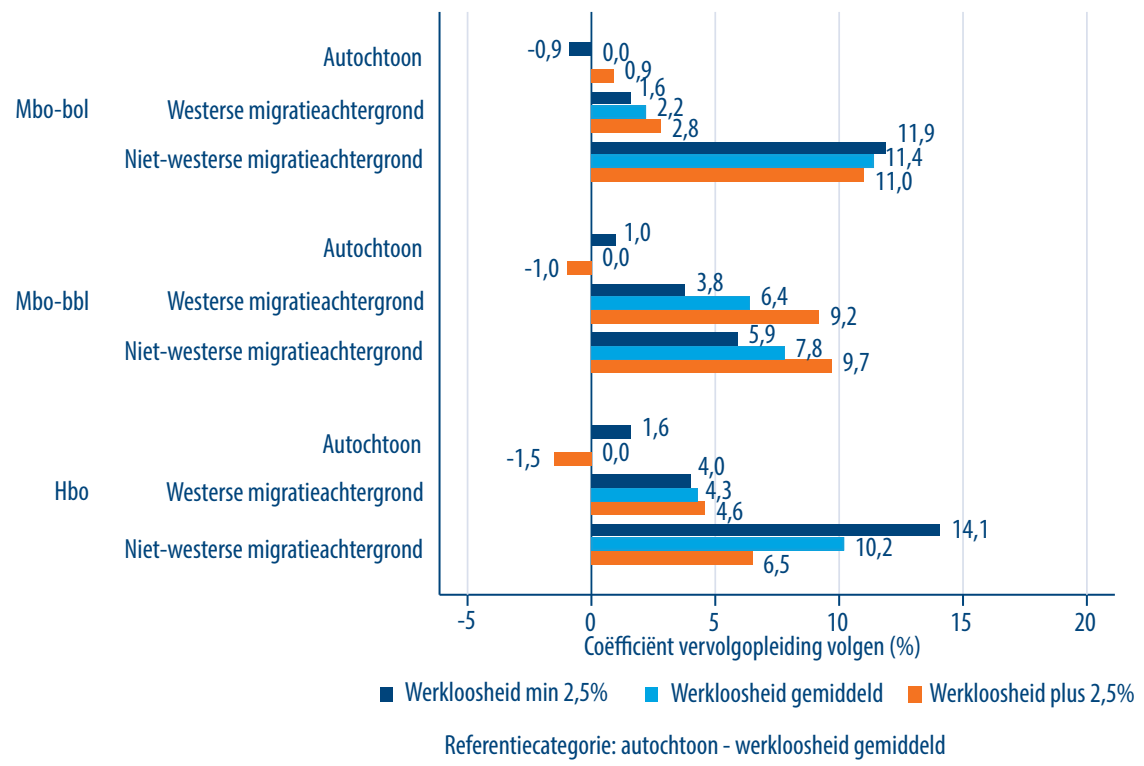

Interacties tussen migratieachtergrond en conjuncturele werkloosheid significant op 1\% niveau voor hbo; geen significantie interactie voor mbo-bol en mbo-bbl

Bron: SIS ROA, 2003-2017

Personen met een laag gemiddeld eindcijfer studeren minder vaak door. Laagconjunctuur verlaagt de kans op het volgen van een vervolgopleiding vooral voor hbo-gediplomeerden met lage eindcijfers.
Figuur 3.3 toont hoe de effecten van de stand van de conjunctuur op de kans op vervolgopleiding variëren naargelang het gemiddelde eindcijfer. Daarbij worden een 6 en een 8 respectievelijk gedefinieerd als een hoog en laag gemiddeld eindcijfer. Personen met een 6 als gemiddeld eindcijfer studeren bij alle opleidingsniveaus minder door, hetgeen mogelijk wordt gedreven door een lagere gepercipieerde toekomstige slaagkans of een lagere intrinsieke studiemotivatie van zwakker scorende gediplomeerden. Onder hbo'ers blijken afgestudeerden met hoge cijfers vaker door te studeren ongeacht de stand van de conjunctuur, terwijl afgestudeerden met lage cijfers die keuze vooral bij hoogconjunctuur maken. Bij mbo-bbl is een soortgelijk patroon te zien, al zijn de interacties tussen eindcijfer en conjuncturele werkloosheid niet significant in dat geval. Bij mbo-bol is dit patroon niet terug te zien, en lijken zowel afgestudeerden met hoge cijfers als afgestudeerden met lage cijfers zich meer door de stand van de conjunctuur te laten leiden dan afgestudeerden met middelmatige cijfers. 
FIGUUR 3.3 Relatie tussen gemiddeld eindcijfer en de keuze voor een vervolgopleiding bij hoge en lage werkloosheid

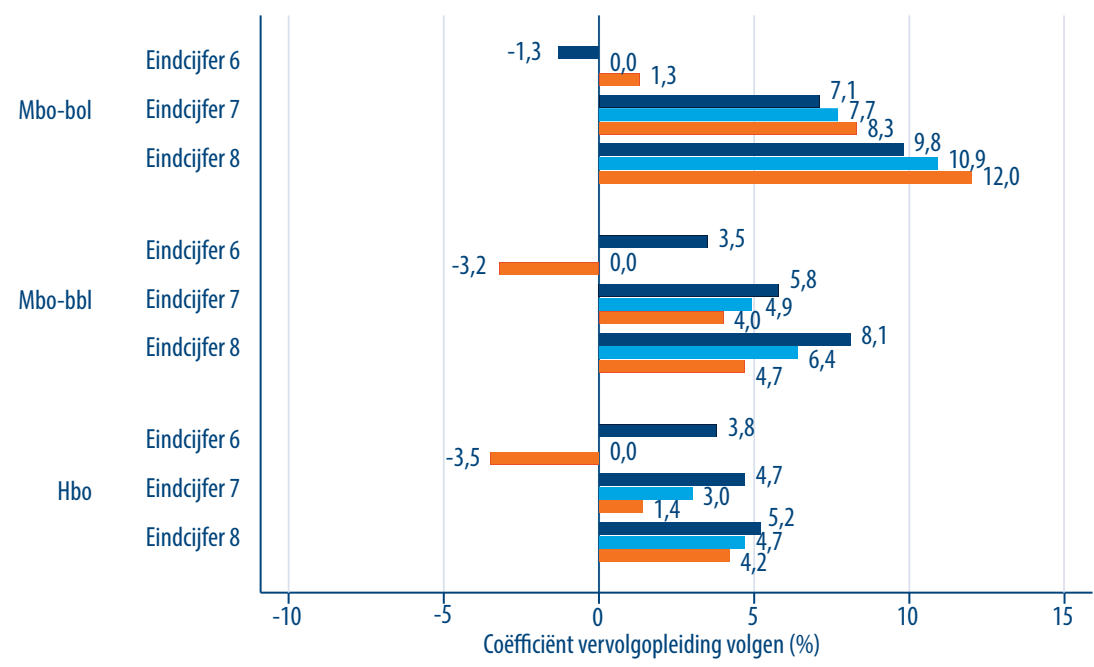

- Werkloosheid $\min 2,5 \%$ Werkloosheid gemiddeld Werkloosheid plus 2,5\%

Referentiecategorie: eindcijfer 6 - werkloosheid gemiddeld

Interactie tussen eindcijfer en conjuncturele werkloosheid significant op 1\% niveau voor hbo en op $5 \%$ niveau voor mbo-bol; geen significante interactie voor mbo-bbl

Bron: SIS ROA, 2003-2017

Laagconjunctuur leidt vooral bij mannen en in mindere mate ook bij vrouwen tot een verlaging van de cursusdeelname.
Naast de uitkomsten voor vervolgopleiding is het eveneens interessant om te onderzoeken op welke manier laagconjunctuur invloed heeft op de cursusdeelname van verschillende deelpopulaties. Figuur 3.4 toont de uitkomsten voor geslacht. Daaruit blijkt allereerst dat mannen van elk van de drie onderscheiden opleidingsniveaus vaker een bedrijfscursus of -training volgen dan vrouwen. De cursusdeelname van vooral mannen wordt sterk negatief beïnvloed door een laagconjunctuur, al is dit effect alleen bij hbo-afgestudeerden significant. 
FIGUUR 3.4 Man-vrouw verschillen in de cursusdeelname bij hoge en lage werkloosheid

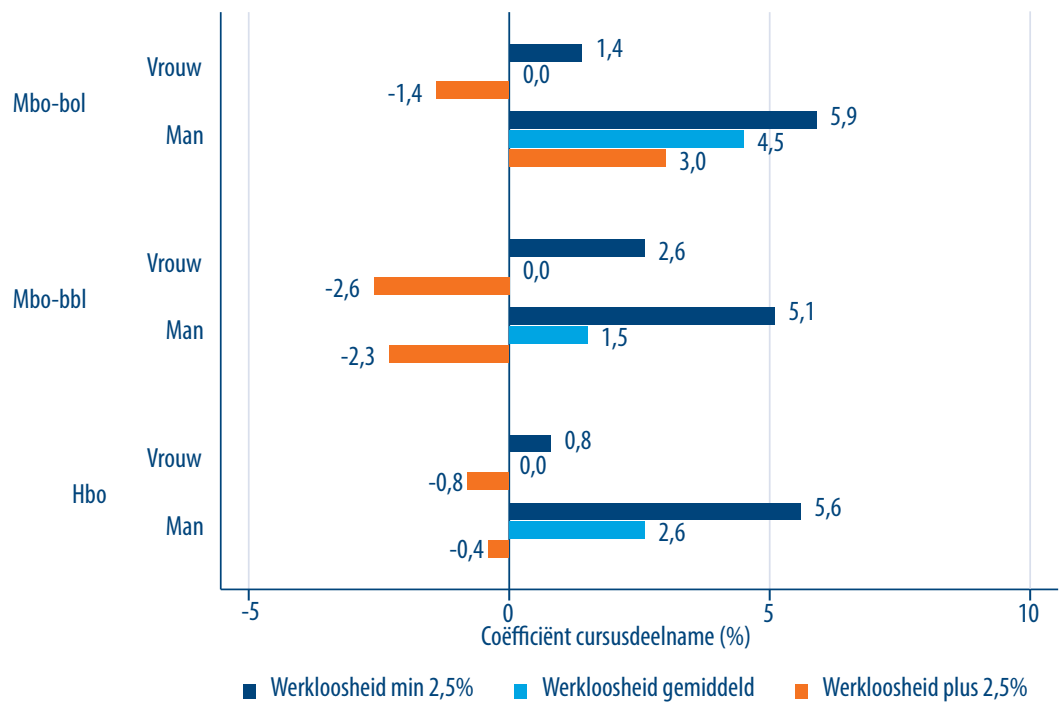

Referentiecategorie: vrouw - werkloosheid gemiddeld

Interactie tussen geslacht en conjuncturele werkloosheid significant op 1\% niveau voor hbo; geen significantie interactie voor mbo-bol en mbo-bbl

Bron: SIS ROA, 2003-2017

Personen met een migratieachtergrond maken minder kans op een bedrijfscursus dan autochtonen. Laagconjunctuur vergroot bovendien dit verschil.
Figuur 3.5 geeft de conjunctuurafhankelijke invloed van etniciteit weer op de kans op cursusdeelname. Personen met een migratieachtergrond maken beduidend minder kans om een bedrijfscursus of -training te

volgen dan autochtonen. Dit verschil wordt bovendien sterker tijdens perioden waarin het economisch slechter gaat. Het grootste effect geldt daarbij voor westerse mbo bblgediplomeerden, waarvoor de kans op cursusdeelname met meer dan 13 procentpunten afneemt wanneer de conjuncturele werkloosheid met 2,5 procentpunten toeneemt. Ook bij het hbo geldt het sterkste effect van een laagjunctuur bij afgestudeerden met een westerse migratieachtergrond. Bij mbo-bol zijn het echter juist afgestudeerden met een niet-westerse migratieachtergrond die in hun scholingskansen het zwaarst door de crisis zijn getroffen. 
FIGUUR 3.5 Relatie tussen etniciteit en de cursusdeelname bij hoge en lage werkloosheid

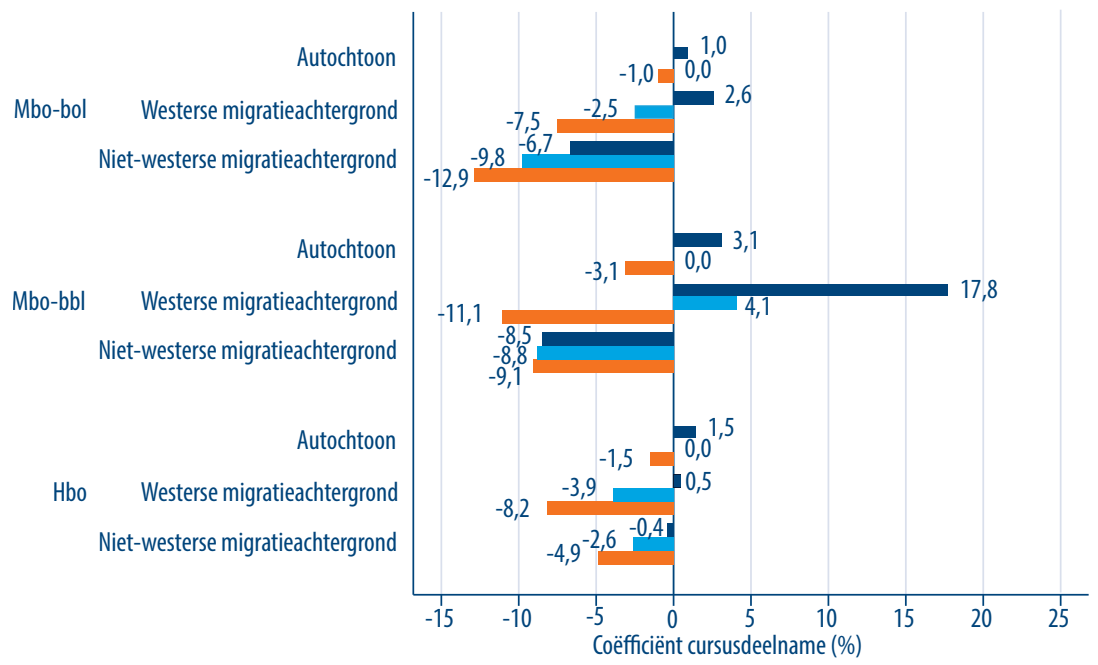

— Werkloosheid $\min 2,5 \%$ — Werkloosheid gemiddeld — Werkloosheid plus 2,5\%

Referentiecategorie: autochtoon - werkloosheid gemiddeld

Interacties tussen westerse migratieachtergrond en conjuncturele werkloosheid zijn significant negatief op $5 \%$ niveau voor hbo en op $10 \%$ niveau voor mbo-bbl; de interactie tussen niet-westerse migratieachtergrond en conjuncturele werkloosheid is significant negatief op $5 \%$ niveau voor mbo-bol; de overige interacties met etniciteit zijn niet significant

Bron: SIS ROA, 2003-2017

Schoolverlaters met een relatief laag eindcijfer volgen minder vaak een cursus, maar het effect van een laagconjunctuur is niet eenduidig naar opleidingsniveau. of -training te volgen. Het effect van laagconjunctuur is echter niet eenduidig en bij alle onderwijsniveaus behalve bij mbo-bbl significant. Bij mbo-bbl blijken schoolverlaters met middelmatige eindcijfers juist zwaarder in hun scholingskansen door de crisis te zijn getroffen dan schoolverlaters met hoge of lage cijfers. 
FIGUUR 3.6 Relatie tussen het gemiddeld eindcijfer en de cursusdeelname bij hoge en lage werkloosheid

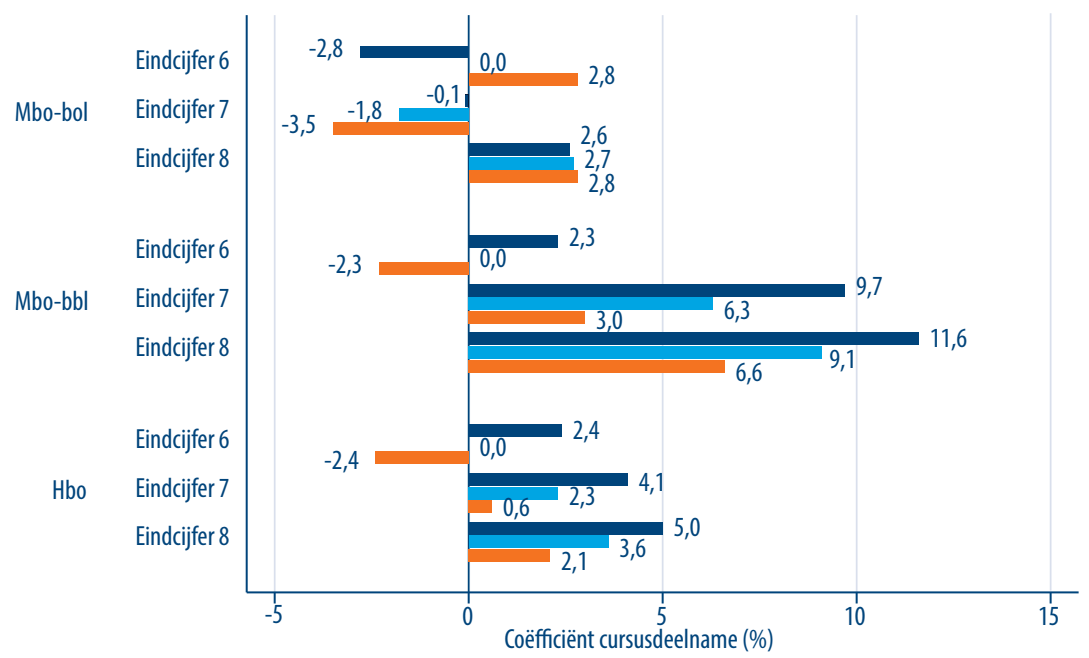

- Werkloosheid $\min 2,5 \%$ Werkloosheid gemiddeld — Werkloosheid plus 2,5\%

Referentiecategorie: eindcijfer 6 - werkloosheid gemiddeld

Interactie tussen eindcijfer en conjuncturele werkloosheid significant op 5\% niveau voor mbo-bbl; geen significante interacties voor de andere opleidingsniveaus

Bron: SIS ROA, 2003-2017 


\section{WELKE GEVOLGEN HEEFT HET ONTBREKEN VAN LEERMOGELIJKHEDEN VOOR DE VROEGE LOOPBAAN VAN SCHOOLVERLATERS?}

In het vorige hoofdstuk werden er significante relaties gevonden tussen perioden van economische crisis en veranderingen in de drie vormen van leergedrag van recent afgestudeerden. Mbo'ers die geconfronteerd worden met een relatief hoge conjuncturele werkloosheid zijn meer geneigd om een vervolgopleiding te volgen, en maken minder kans op een cursus of -training. Hbo'ers volgen daarentegen minder vaak een vervolgopleiding in crisistijd, maar verlengen wel vaker hun studieduur en maken eveneens minder kans op een cursus of -training. Het leergedrag van schoolverlaters met een migratieachtergrond lijkt bovendien sterker door de stand van de conjunctuur te worden beïnvloed.

Dit roept de vraag op in welke mate de in hoofdstuk 3 geconstateerde effecten van een laagconjunctuur op het leergedrag van mbo- en hbo-schoolverlaters gevolgen heeft voor de vroege loopbaan van schoolverlaters. Om deze vraag te kunnen beantwoorden, onderzoeken we de relatie tussen de conjuncturele werkloosheid in het jaar van afstuderen en de arbeidsmarktuitkomsten op korte termijn (één jaar na afstuderen) en middellange termijn (tussen de vier en de acht jaar na afstuderen). ${ }^{16}$ Het volgen van een vervolgopleiding of bedrijfscursus fungeren daarbij als mediërende variabelen. De arbeidsmarktuitkomsten waar we ons in dit hoofdstuk op zullen richten betreffen de kans op werk, de kans op een baan in het kerndomein, het bruto uurloon, de kans op een vaste aanstelling en de baantevredenheid.

De rest van het hoofdstuk is als volgt opgebouwd. Allereerst schatten we de directe relatie tussen de conjuncturele werkloosheid bij afstuderen en de verschillende arbeidsmarktuitkomsten op korte en middellange termijn. Daarna introduceren we de vervolgopleiding als mediërende variabele in het model, en gaan we na in hoeverre deze additionele variabele de rechtstreekse impact van de laagconjunctuur op de arbeidsmarktuitkomsten op korte en middellange termijn wijzigt. Ten slotte doen we hetzelfde voor de mediërende invloed van cursusdeelname. In de analyses maken we steeds een onderscheid tussen mbo- en hbo-gediplomeerden.

16 Daarbij maken we gebruik van kruiselings-vertraagde structurele vergelijkingsmodellen (cross-lagged structural equation models). Zie tekstbox 1. 
TEKSTBOX $_{1}$ Kruiselings-vertraagde structurele vergelijkingsmodellen

Een structureel vergelijkingsmodel is een multivariaat regressiemodel dat de standaard regressie uitbreidt door het simultaan schatten van meerdere uitkomstvariabelen. Voor elk van deze endogene variabelen er is een overeenkomstige regressievergelijking, die ook van de andere endogene variabelen kan afhangen. Exogene variabelen verwijzen hier naar de voorspellende variabelen (covariaten) die niet worden bepaald door een andere variabele in het model. Een kruiselings-vertraagd structureel vergelijkingsmodel houdt rekening met de temporele volgorde van longitudinale gegevens door het modelleren van een vertraagde structuur, waarbij $Y$ op tijdstip $t+1$ veroorzaakt wordt door $X$ op tijdstip $t$, of $Y$ op tijdstip t veroorzaakt wordt door X op tijdstip t-1 (Pakpahan et al., 2015). Naast kruiselings-vertraagde parameters, wordt de temporele volgorde ook weergegeven door autoregressieve parameters, dat wil zeggen $X$ op tijdstip t heeft invloed op $X$ op tijdstip $t+1$, en analoog voor $Y$.

\subsection{Heeft laagconjunctuur op middellange termijn invloed op arbeidsmarktuitkomsten?}

Tabel 4.1 toont het effect van de conjuncturele werkloosheid op vijf arbeidsmarktuitkomsten op zowel korte als middellange termijn. Op korte termijn (één jaar na afstuderen) heeft de conjuncturele werkloosheid een negatieve invloed op de kans op werk, het hebben van een baan in het kerndomein van de opleiding, het bruto uurloon en het hebben van een vast contract. Het effect op baantevredenheid is echter niet statistisch significant. Bovendien valt op dat voor hbo'ers de negatieve effecten op bruto uurloon en de kans op een vast contract aanzienlijk groter zijn dan voor mbo'ers.

Als we op middellange termijn kijken, zien we dat vier tot acht jaar na afstuderen de effecten op de meeste arbeidsmarktuitkomsten verdwenen zijn, maar met betrekking tot de baankans van mbo-schoolverlaters is er echter nog steeds een negatief effect zichtbaar. Voor de hbo'ers is er op de middellange termijn zelfs sprake van een zwak maar positief effect van de laagconjunctuur op de kans op werk. Voor de mbo'ers strookt deze uitkomst niet met de bevinding van Wolbers (2014) dat arbeidsmarktintrede in tijden van hoge werkloosheid weliswaar een negatieve impact heeft op de latere kans op werk, maar dat dit effect acht jaar na schoolverlaten verdwenen is. Het zwak positieve effect van de laagconjunctuur op de kans op werk op de middellange termijn voor de hbo'ers zou het gevolg kunnen zijn van het verlengen van de studieduur in crisistijd (zie Tabel 3.2), waardoor schoolverlaters op middellange termijn meer kans maken op de arbeidsmarkt. Ook zou dit een gevolg kunnen zijn van het cursusgedrag of het volgen van een vervolgopleiding in tijden van laagconjunctuur. In de volgende paragrafen zullen we hierop ingaan. Afgezien van het negatieve effect op de kans op werk voor mbo'ers, is de afwezigheid van significante effecten op de arbeidsmarktuitkomsten op 
middellange termijn in lijn met de bestaande literatuur (Genda et al., 2010; Liu et al. 2016; Van den Berge \& Brouwers, 2016).

TABEL 4.1 Marginale effecten van conjuncturele werkloosheid op arbeidsmarktuitkomsten één en vier tot acht jaar na afstuderen

\begin{tabular}{|c|c|c|c|}
\hline & & Korte termijn na afstuderen & Middellange termijn na afstuderen \\
\hline \multicolumn{4}{|c|}{ MBO } \\
\hline & Kans op werk & $-0,7 \% * *$ & $-0,6 \% * *$ \\
\hline & Baan in kerndomein & $-1,4 \% * *$ & $-1,3 \%$ \\
\hline & Bruto uurloon & $-1,7 \%^{* * *}$ & $-0,1 \%$ \\
\hline & Vast contract & $-3,2 \% * * *$ & $-0,3 \%$ \\
\hline & Baantevredenheid & $-2,2 \%$ & $1,6 \%$ \\
\hline \multicolumn{4}{|c|}{ HBO } \\
\hline & Kans op werk & $-0,7 \% * *$ & $0,8 \% *$ \\
\hline & Baan in kerndomein & $-1,3 \% *$ & $-0,7 \%$ \\
\hline & Bruto uurloon & $-2,6 \% * * *$ & $-0,2 \%$ \\
\hline & Vast contract & $-4,3 \% * * *$ & $-0,6 \%$ \\
\hline & Baantevredenheid & $-2,4 \%$ & $-0,1 \%$ \\
\hline
\end{tabular}

*** $\mathrm{p}<0.01,{ }^{* *} \mathrm{p}<0.05,{ }^{*} \mathrm{p}<0.1$

Bron: SIS ROA (2003-2017) en de ROA T+5-meting.

Bij de mbo-analyses werd gecontroleerd voor geslacht, leeftijd, etniciteit en eindcijfer. Bij de hboanalyses werd daarnaast ook gecontroleerd voor de hoogst voltooide vooropleiding en de bruto studieduur.

\subsection{Middellangetermijneffecten van laagconjunctuur die via doorstroom naar vervolgonderwijs lopen}

Paragraaf 4.1 liet zien dat de rechtstreekse effecten van een laagconjunctuur op de arbeidsmarktuitkomsten zwakker worden naarmate schoolverlaters langer op de arbeidsmarkt zijn, en dat er na vier tot acht jaar alleen nog een significant effect op de kans op werk blijft bestaan. In deze paragraaf onderzoeken we hoe de marginale effecten veranderen wanneer we rekening houden met het volgen van vervolgonderwijs kort na het verlaten van de initiële opleiding. De totale effecten worden hierbij ontleed in een direct effect van een laagconjunctuur - het deel van het effect dat overeind blijft na controle voor het wel of niet doorstromen naar vervolgonderwijs - en een indirect effect - dat deel dat loopt via vervolgonderwijs. We spreken van een indirect effect wanneer zowel het effect van laagconjunctuur op de kans op doorstroom naar vervolgonderwijs, als het effect van vervolgonderwijs op de betreffende uitkomst, statistisch significant zijn. 
Het zijn vooral de indirecte effecten die van belang zijn voor de conclusies van dit rapport, omdat het de effecten van een laagconjunctuur betreft die specifiek toe te schrijven zijn aan een verandering in leergedrag als gevolg van de economische crisis. We richten ons hierbij voornamelijk op effecten op uitkomsten op de middellange termijn, omdat het hier - anders dan bij kortetermijneffecten - aannemelijk is dat een eventuele verandering in menselijk kapitaal als gevolg van leeractiviteiten op korte termijn zichtbaar terug te zien in de arbeidsmarktuitkomsten. Op korte termijn is de verstreken tijd tussen leeractiviteit en uitkomst immers zo kort dat we oorzaak en gevolg moeilijk van elkaar kunnen onderscheiden. Omdat vervolgonderwijs op zichzelf een kortetermijnuitkomst is voor pas afgestudeerden, worden bij deze analyses de effecten op kortetermijnuitkomsten buiten beschouwing gelaten, en wordt alleen naar de effecten op uitkomsten op de middellange termijn gekeken.

Figuur 4.1 toont voor mbo-schoolverlaters de relaties tussen de conjuncturele werkloosheid bij arbeidsmarktintrede, het volgen van een vervolgopleiding en de vijf arbeidsmarktuitkomsten op de middellange termijn. In tegenstelling tot de analyse in hoofdstuk 3 zien we hier voor de mbo'ers geen significant effect van de laagconjunctuur op het volgen van vervolgonderwijs. Dit is wellicht een gevolg van het feit dat we vanwege het betrekkelijk kleine aantal observaties ${ }^{17}$ hier de effecten voor mbo-bol en mbo-bbl combineren. Het kleinere aantal observaties kan eveneens het vaststellen van significante bemoeilijken. Echter, gezien het feit dat er voor geen van de uitkomstvariabelen sprake is van een sterk effect van het volgen van een vervolgopleiding, lijkt er hoe dan ook geen reden te zijn om aan te nemen dat er een effect van de crisis is op arbeidsmarktuitkomsten van mbo'ers bestaat dat loopt via een eventueel gewijzigde kans op doorstroom naar vervolgonderwijs. De (directe) marginale effecten van conjuncturele werkloosheid op de verschillende arbeidsmarktuitkomsten blijven overigens ongewijzigd bij de introductie van vervolgonderwijs als mediërende variabele (zie Tabel 4.1 ter vergelijking). Kortom, de invloed van een relatief hoge conjuncturele werkloosheid bij arbeidsmarktintrede op de arbeidsmarktuitkomsten van mbo'ers op de middellange termijn lijkt niet te lopen via een effect op het al dan niet volgen van een vervolgopleiding. 


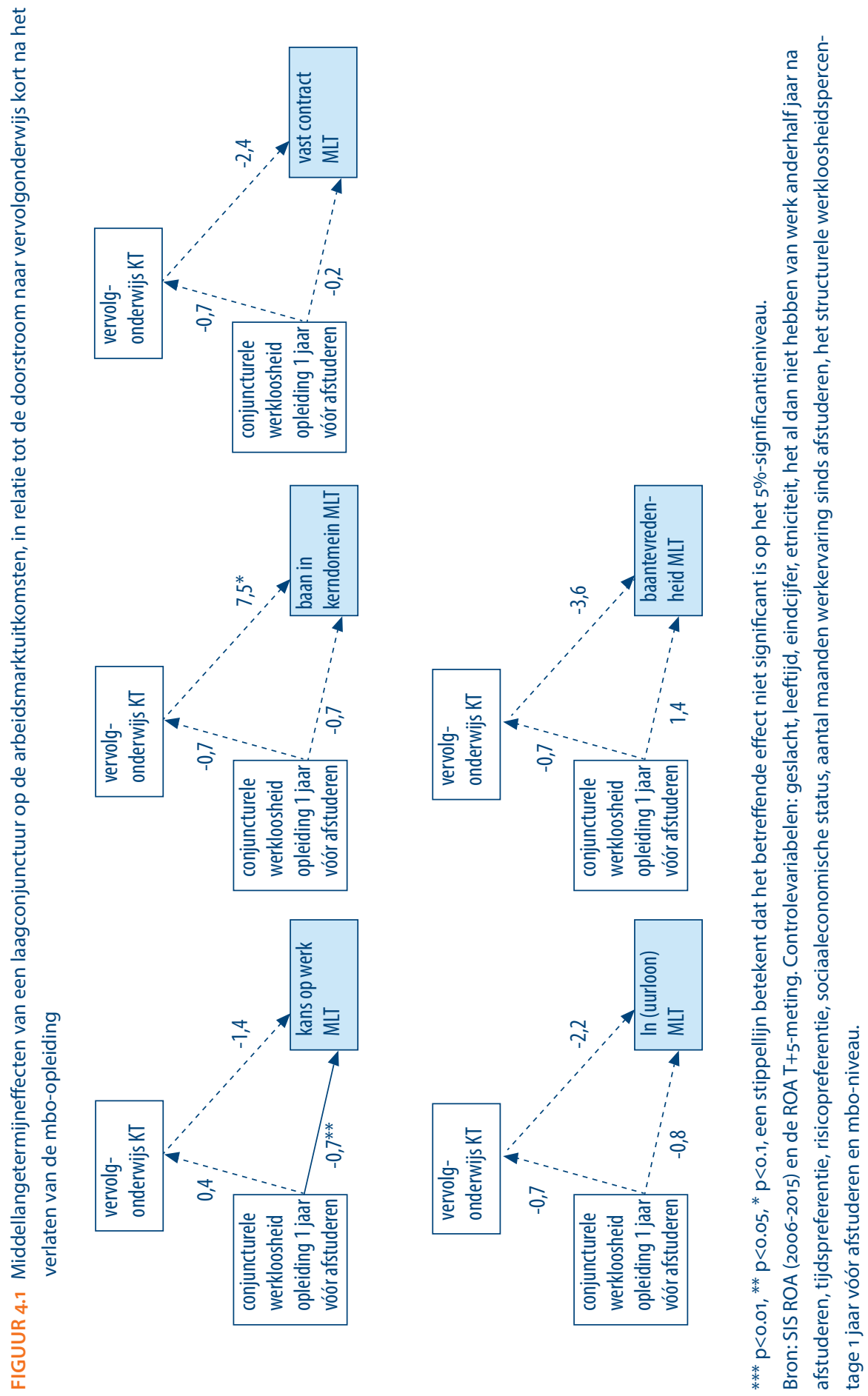


De doorstroom naar vervolgonderwijs lijkt voor zowel mbo'ers als hbo'ers geen pad te zijn waarlangs conjuncturele werkloosheid bij arbeidsmarktintrede invloed heeft op de arbeidsmarktuitkomsten op middellange termijn.
Figuur 4.2 geeft de resultaten van eenzelfde analyse voor de hbo'ers weer. Ook hier zien we, nogmaals in tegenstelling tot de analyse in hoofdstuk 3, geen significant effect van de laagconjunctuur op het volgen van vervolgonderwijs. Wel zien we dat voor twee uitkomsten - de kans op een baan in

het kerndomein en de kans op een vast contract - een sterk significant effect van het volgen van een vervolgopleiding. Het tweede effect - op de kans op een vast contract is echter negatief. Per saldo is er dus ook voor hbo'ers geen reden om aan te nemen dat er een noemenswaardig effect van de crisis is op arbeidsmarktuitkomsten dat via een eventueel gewijzigde kans op doorstroom naar vervolgonderwijs loopt. Net als bij mbo blijven de (directe) marginale effecten van conjuncturele werkloosheid op de verschillende arbeidsmarktuitkomsten grotendeels ongewijzigd bij de introductie van vervolgonderwijs als mediërende variabele (zie Tabel 4.1). 

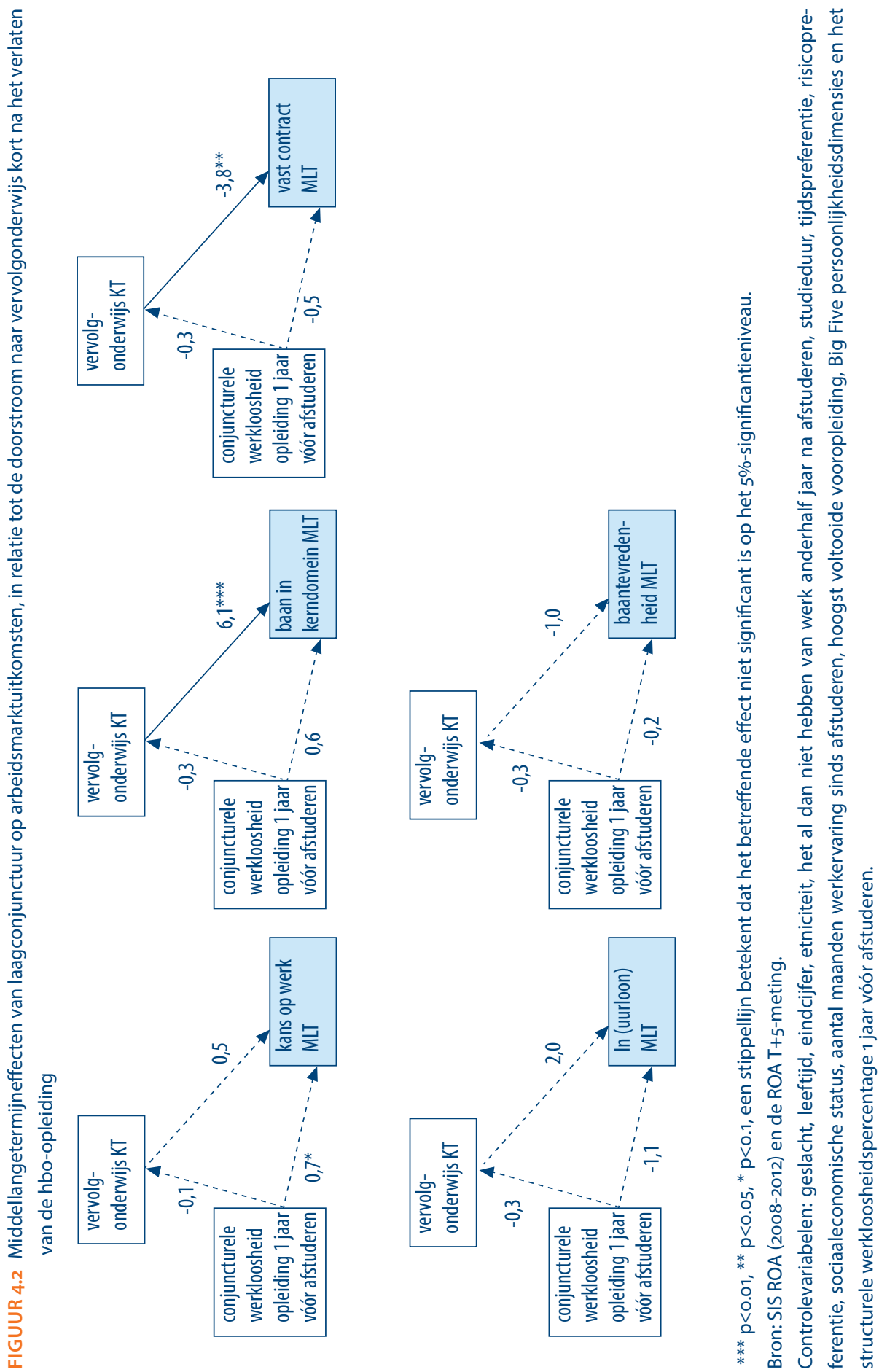


\subsection{Middellangetermijneffecten van laagconjunctuur die via cursusdeelname lopen}

In deze paragraaf gaan we in op het effect van cursusdeelname op de arbeidsmarktuitkomsten op middellange termijn. Anders dan bij de analyses van de effecten die via vervolgonderwijs lopen, worden in deze modellen arbeidsmarktuitkomsten op zowel de korte als de middellange termijn bij de analyses meegenomen. Hierbij dient te worden opgemerkt dat alleen de effecten van cursusdeelname op middellangetermijnuitkomsten als causaal worden opgevat. Omdat cursusdeelname en kortetermijnuitkomsten nagenoeg gelijktijdig plaatsvinden, kan namelijk aan deze relatie geen causale interpretatie worden verbonden. Het is wel belangrijk om ze als controlevariabelen in de analyses mee te nemen, om te voorkomen dat kortetermijneffecten die primair aan een gunstige start op de arbeidsmarkt liggen ten onrechte worden toegeschreven aan de verhoogde kans op cursusdeelname die daarbij gepaard gaat.

Figuur 4.3 geeft voor de mbo'ers het effect van de conjuncturele werkloosheid bij arbeidsmarktintrede en de cursusdeelname weer op zowel de korte als middellange termijn op de vijf onderscheiden arbeidsmarktuitkomsten. In hoofdstuk 3 werd reeds vastgesteld dat een laagconjunctuur negatieve invloed heeft op de cursusdeelname, en eenzelfde effect is ook hier aanwezig. Ook verhoogt, zoals verwacht, de cursusdeelname kort na het schoolverlaten de kans op cursusdeelname op de middellange termijn. Er is ook een direct effect van cursusdeelname op de korte en middellange termijn op de beloning op middellange termijn, en van cursusdeelname op de middellange termijn op de kans op een baan in het eigen kerndomein op de middellange termijn. Voor deze twee uitkomstvariabelen is dus sprake van één of meerdere paden die van de laagconjunctuur via cursusdeelname naar arbeidsmarktuitkomsten op middellange termijn lopen.

Voor de overige uitkomstvariabelen is het beeld minder duidelijk. Hoewel er een effect is van laagconjunctuur op cursusdeelname, lijkt dit effect zich niet te vertalen in een verhoogde kans op werk, vast contract, of hogere mate van baantevredenheid. Het feit dat er effecten op beloning en werk in het kerndomein zijn die via cursusdeelname lopen, suggereert echter dat het dempend effect van een laagconjunctuur op cursusdeelname blijvende gevolgen kan hebben voor de beroepsloopbanen van mbo-schoolverlaters. De directe effecten van conjuncturele werkloosheid op arbeidsmarktuitkomsten blijven overigens grotendeels ongewijzigd bij de introductie van cursusdeelname als mediërende variabele (zie Tabel 4.1). 


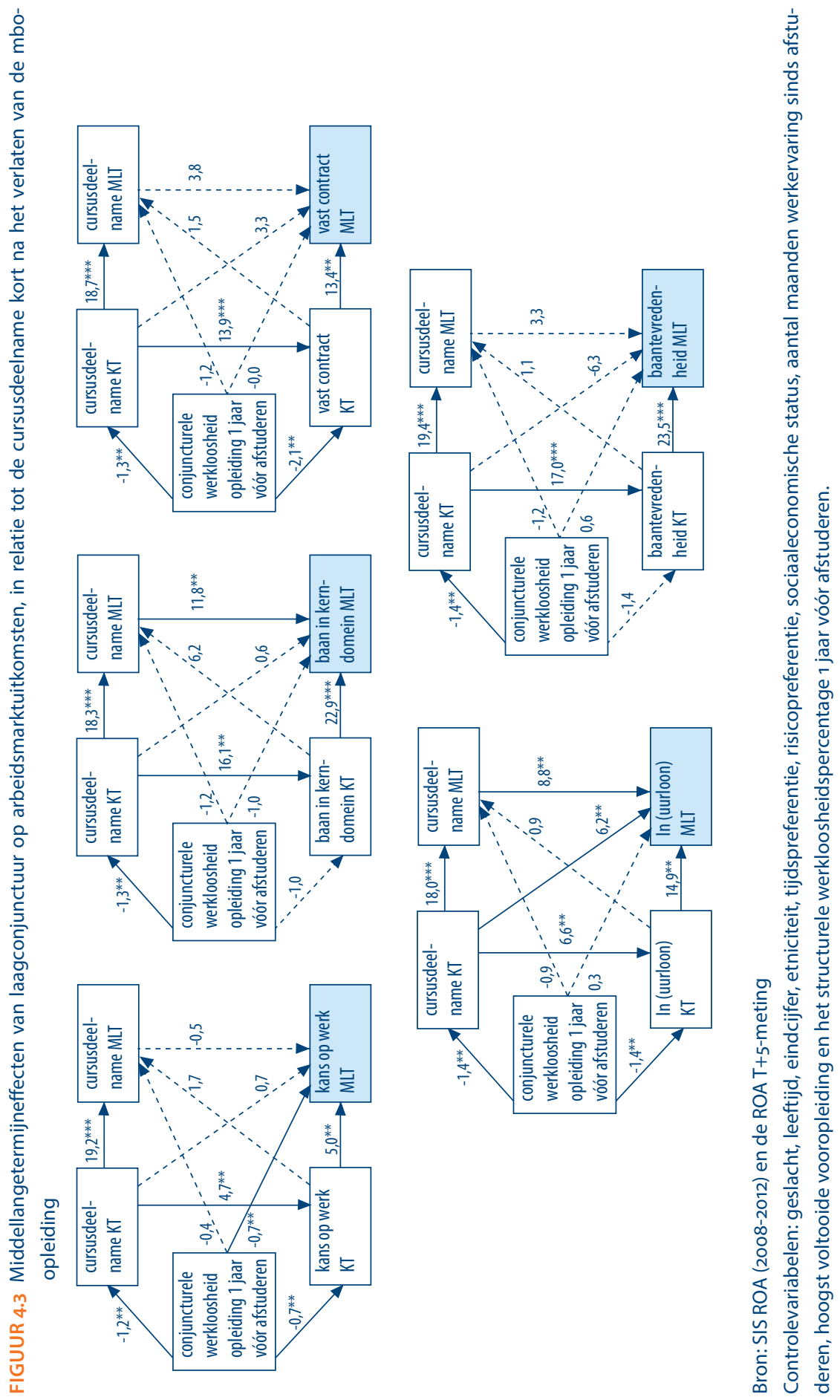


Figuur 4.4 toont de resultaten voor de hbo'ers. Net als voor mbo'ers werd in hoofdstuk 3 vastgesteld dat een laagconjunctuur een negatieve invloed heeft op de deelname aan cursussen, en eenzelfde effect is ook hier aanwezig. Ook hier verhoogt de cursusdeelname kort na het schoolverlaten de kans op cursusdeelname op de middellange termijn. Er is bovendien voor alle uitkomsten een sterk effect van cursusdeelname op middellange termijn, hetgeen betekent dat er in alle gevallen een onafgebroken pad is van conjuncturele werkloosheid via cursusdeelname op korte en middellange termijn naar arbeidsmarktuitkomsten op middellange termijn. Daarnaast is er eveneens een effect van cursusdeelname op korte termijn op de kans op werk op middellange termijn. Alles bij elkaar suggereert dit dat het dempend effect van een laagconjunctuur op cursusdeelname, nog meer dan bij mbo'ers, blijvende gevolgen kan hebben voor de loopbaan van afgestudeerden.

De directe effecten van conjuncturele werkloosheid op arbeidsmarktuitkomsten blijven overigens grotendeels ongewijzigd bij de introductie van cursusdeelname als mediërende variabele (zie Tabel 4.1). 


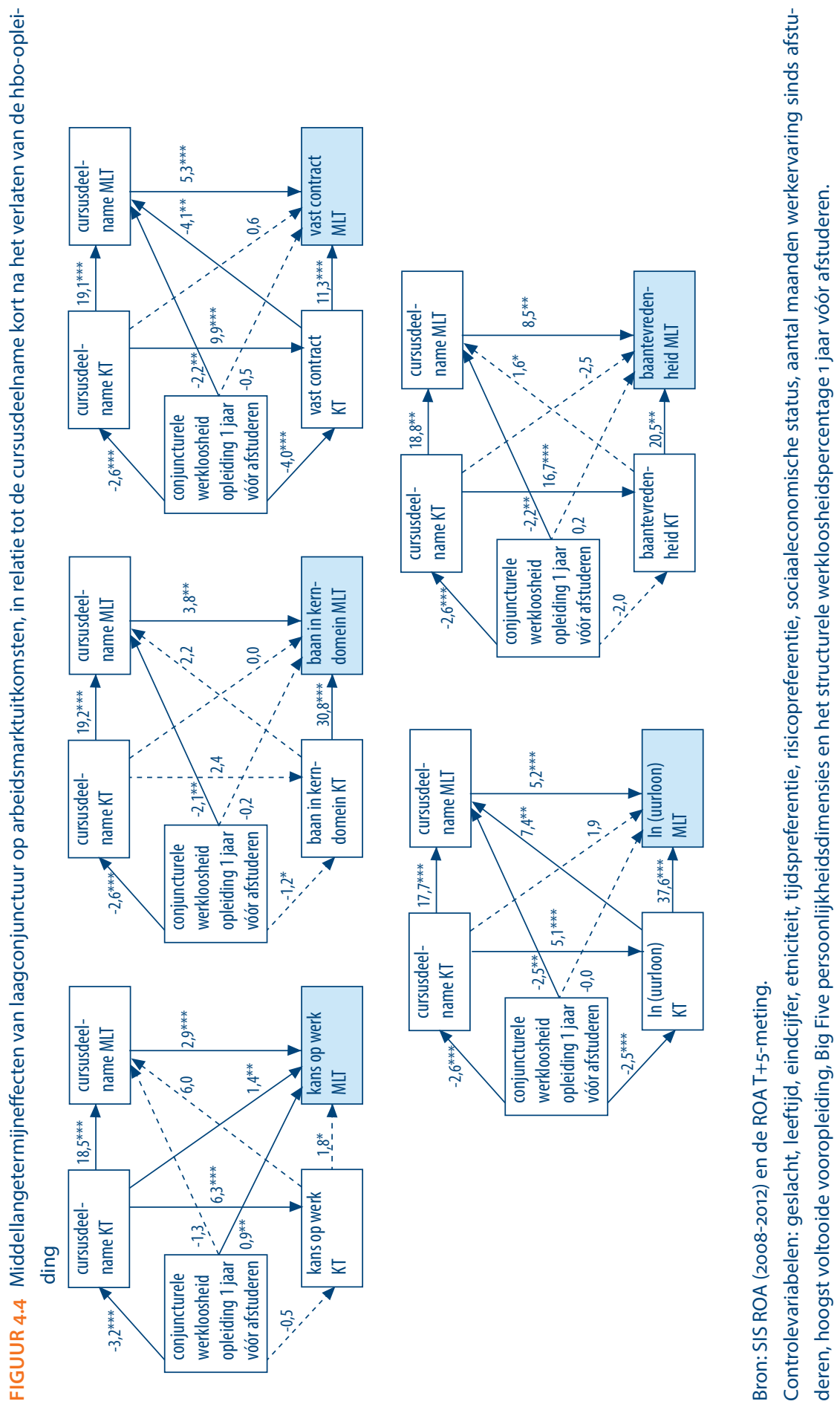




\subsection{Mediatie-analyse voor de rol van cursusdeelname}

In deze laatste paragraaf onderzoeken we welk deel van het totale effect van een crisisperiode op de verschillende arbeidsmarktuitkomsten op middellange termijn toe te schrijven is aan het effect dat indirect via cursusdeelname loopt. De resultaten van deze mediatie-analyse zijn opgenomen in Tabel 4.2. Omdat we eerder in dit hoofdstuk geen aanwijzingen vonden dat het volgen van een vervolgopleiding een belangrijke mediator is waarlangs conjuncturele werkloosheid invloed heeft op de arbeidsmarktuitkomsten op middellange termijn (zie Figuren 4.1 en 4.2), is deze analyse uitsluitend gedaan voor de invloed van cursusdeelname.

Voor het totale effect berekenen we de gezamenlijke impact van alle mogelijke paden waarlangs conjuncturele werkloosheid een effect kan hebben op de arbeidsmarktuitkomsten op middellange termijn. Voor het indirecte effect kijken we naar de som van twee paden:

1. Het effect van de conjuncturele werkloosheid op de cursusdeelname op de korte termijn, dat vervolgens een rechtstreeks effect heeft op de arbeidsmarktuitkomst op middellange termijn.

2. Het effect van de conjuncturele werkloosheid op de cursusdeelname op de korte termijn, dat vervolgens een rechtstreeks effect heeft op cursusdeelname op middellange termijn, wat vervolgens een rechtstreeks effect heeft op de arbeidsmarktuitkomst op middellange termijn.

We sluiten bij dit indirecte effect dus het pad uit dat loopt via cursusdeelname op de korte termijn naar de arbeidsmarktuitkomsten op de korte termijn en vervolgens naar de arbeidsmarktuitkomsten op middellange termijn. De causaliteit bij dit effect is namelijk onduidelijk, en loopt naar verwachting eerder van de arbeidsmarktuitkomst op de korte termijn naar de cursusdeelname op de korte termijn dan andersom.

Uit de tabel blijkt dat een hoge conjuncturele werkloosheid bij afstuderen op middellange termijn voor mbo-gediplomeerden alleen een significante en negatieve invloed heeft op de kans op een baan en de kans op een baan in het kerndomein. Het indirecte effect dat loopt via cursusdeelname op korte termijn is echter voor alle uitkomstvariabelen niet significant.

Voor hbo'ers vinden we wel een significant negatief indirect effect van de conjuncturele werkloosheid via de cursusdeelname op de korte termijn op de kans op werk en een vast contract op de middellange termijn. Vanwege het positieve directe effect van de conjuncturele werkloosheid op de kans op werk op de middellange termijn (zie Figuur 4.4), is het totale effect echter niet significant. Voor de kans op een vast contract zijn zowel het directe als het indirecte effect significant negatief. Het aandeel van het indirecte effect van conjuncturele werkloosheid op de kans op een vast contract dat loopt 
via de cursusdeelname op de korte termijn bedraagt ongeveer $15 \%$ van het totale effect van de conjuncturele werkloosheid.

TABEL 4.2 Mediatie-analyse voor de rol van cursusdeelname

\begin{tabular}{|c|c|c|c|c|}
\hline \multirow[t]{2}{*}{ Uitkomstvariabele } & \multicolumn{2}{|c|}{ Indirecte effect } & \multicolumn{2}{|c|}{ Totale effect } \\
\hline & Coëfficiënt & P-waarde & Coëfficiënt & P-waarde \\
\hline \multicolumn{5}{|l|}{ MBO } \\
\hline Kans op werk & $-0,003$ & 0,900 & $-0,173$ & $0,038^{* *}$ \\
\hline Baan in kerndomein & $-0,030$ & 0,158 & $-0,242$ & $0,021^{* *}$ \\
\hline Vast contract & $-0,021$ & 0,255 & $-0,135$ & 0,051 \\
\hline Baantevredenheid & 0,002 & 0,742 & 0,001 & 0,970 \\
\hline Bruto uurloon & $-0,003$ & 0,060 & $-0,003$ & 0,799 \\
\hline \multicolumn{5}{|l|}{ HBO } \\
\hline Kans op werk & $-0,171$ & $0,002^{* * *}$ & $-0,190$ & 0,378 \\
\hline Baan in kerndomein & $-0,023$ & 0,148 & $-0,204$ & $0,025^{* *}$ \\
\hline Vast contract & $-0,041$ & $0,029^{* *}$ & $-0,267$ & $0,000^{* * *}$ \\
\hline Baantevredenheid & $-0,005$ & 0,291 & $-0,020$ & 0,268 \\
\hline Bruto uurloon & $-0,001$ & 0,139 & $-0,012$ & 0,203 \\
\hline
\end{tabular}

Bron: SIS ROA (2008-2012) en de ROA T+5-meting.

De coëfficiënten zijn niet weergegeven als marginale effecten. De p-waarden zijn berekend op basis van bootstrapping. 



\section{LITERATUUR}

Belfi, B., Mommers, A. en Allen, J. (2017). Statistiek: Wo-doorstroom hbo'ers stokt selectief, Economische Statistische Berichten, 102(4748), 184.

Bosch, G. (2010). Dismissing hours not workers: work-sharing in the economic crisis. Chapter IX in J. Heyes, L. Richly (eds.), Labour Administration and the Economic Crisis: Challenges, Responses and Opportunities, ILO, Geneva.

Bowlus, A. J., \& Liu, H. (2003). The Long-term Effects of Graduating from High School During a Recession: Bad Luck or Forced Opportunity? University of Western Ontario, Centre for Human Capital and Productivity (CHCP) Working Papers 20037.

Burgess, S., Propper, C., Rees, H. \& Shearer, A. (2003). The class of 1981: The effects of early career unemployment on subsequent unemployment experiences. Labour Economics, 10(3), 291-309.

Chen, X., \& Yur-Austin, J. (2016). College challenge to ensure "timely graduation": Understanding college students' mindsets during the financial crisis. Journal of Education for Business, 91(1), 32-37.

Dekker, F., \& van der Veen, R. (2017). Modern working life: A blurring of the boundaries between secondary and primary labour markets?. Economic and Industrial Democracy, 38(2), 256-270.

Felstead, A., Green, F., \& Jewson, N. (2012). An analysis of the impact of the 2008-9 recession on the provision of training in the UK. Work, Employment \& Society, 26(6): 968-986.

Figueiredo, H., Biscaia, R., Rocha, V., \& Teixeira, P. (2017). Should we start worrying? Mass higher education, skill demand and the increasingly complex landscape of young graduates' employment. Studies in Higher Education, 42(8), 1401-1420.

Fouarge, D., van Eldert, P., de Grip, A., Künn-Nelen, A., Poulissen, D. (2018). Nederland in leerstand, ROA-R-2018/4

Genda, Y., Kondo, A., \& Ohta, S. (2010). Long-term effects of a recession at labor market entry in Japan and the United States, Journal of Human Resources, 45(1), 157-196. 
Gerards, R., De Grip, A., De Hoon, M., \& Kuenn-Nelen, A., \& Poulissen, D. (2015). Arbeidsmarktmonitor Metalektro 2014, ROA-R-2015/2.

Guo, N. (2018). The effect of an early career recession on schooling and lifetime welfare. International Economic Review, 59(3), 1511-1545.

Hershbein BJ. (2012). Graduating High School in a Recession:Work, Education, and Home Production. The BE journal of economic analysis \& policy, 12(1): Article 3. doi:10.1515/1935-1682.2599.

Inspectie van het Onderwijs (2017) In- en doorstroommonitor 2008-2017, Utrecht: Inspectie van het Onderwijs.

Kahn, L.B. (2010). The long-term labor market consequences of graduating from college in a bad economy. Labour Economics, 17(2), pp. 303-316.

Künn-Nelen, A., Eldert, P. van, Fouarge, D., Grip, A. de, \& Poulissen, D. (2018). Leren onder werkenden met een kwetsbare positie op de arbeidsmarkt. Maastricht: ROA-R-2018/5.

Kyndt, E., \& Baert, H. (2013). Antecedents of employees' involvement in work-related learning: A systematic review. Review of Educational Research, 83(2), 273-313.

Liu, K., Salvanes, K. G., \& Sorensen, E. O. (2016). Good skills in bad times: Cyclical skill mismatch and the long-term effects of graduating in a recession. European Economic Review, 84(C), 3-17.

Luzzo, D., \& McWhirter, E. H. (2001). Sex and Ethnic Differences in the Perception of Educational and Career-Related Barriers and Levels of Coping Efficacy. Journal of counseling and development, 79(1), 61-67.

Oreopoulos, P., T. von Wachter, A. Heisz (2012) .The short- and long-term career effects of graduating in a recession, American Economic Journal: Applied Economics, 4(1), 1-29.

Pakpahan, E., Hoffmann, R., \& Kröger, H. (2015). Statistical methods for causal analysis in life course research: an illustration of a cross-lagged structural equation model, a latent growth model, and an autoregressive latent trajectories model. International Journal of Social Research Methodology, 20(1), 1-19.

Psacharopoulos, G., \& Patrinos, H. A. (2002). Returns to investment in education: a further update. Policy Research Working Paper Series 2881, The World Bank.

Rose, A. K. en Spiegel, M. M. (2009). Cross-Country Causes and Consequences of the 2008 Crisis: Early Warning, Federal Reserve Bank of San Francisco, Working Paper 2009-17. 
Speer, J. (2015). Wages, Hours, and the School-to-Work Transition: The Consequences of Leaving School in a Recession for Less-Educated Men. The B.E. Journal of Economic Analysis \& Policy, 16(1), 97-124.

Van den Berge, W., \& Brouwers, A. (2016). A lost generation? The wage, employment and demographic effects of graduating during a recession. CPB Discussion Paper 356. Centraal Planbureau.

Verbruggen, M., H. van Emmerik, A. van Gils, C. Meng, A. de Grip (2015), Does Early-Career Underemployment Impact Future Career Success? A Path Dependency Perspective, Journal of Vocational Behavior, 90, 101-110.

Wolbers, M. H. J. (2014). Een verloren generatie van jongeren op de arbeidsmarkt? Tijdschrift voor arbeidsvraagstukken, 30(2), 103-119. 



\section{BIJLAGE A}

\section{Databronnen}

In dit rapport wordt gebruik gemaakt van verschillende datasets. In deze bijlage geven we uitleg over waar deze data vandaan komt.

\section{CBS Statline}

Het eerste deel van Hoofdstuk 2 van dit rapport wordt er gebruikt gemaakt van de data van het CBS. De data gebruikt wordt is openbaar beschikbaar in de databank van het CBS Statline. De specifieke datasets die gebruikt zijn binnen Statline staan per figuur als bron vermeld.

\section{SIS ROA}

Het Researchcentrum voor Onderwijs en Arbeidsmarkt (ROA) voert sinds het begin van de jaren negentig in vrijwel alle sectoren van het Nederlandse onderwijsstelsel onderzoek uit onder schoolverlaters. Sinds 1996 is dit schoolverlatersonderzoek in belangrijke mate op elkaar afgestemd en geïntegreerd in het zogenoemde Schoolverlatersinformatiesysteem (SIS). Dit systeem beoogt een monitoringsinstrument van de transitie van school naar werk over de volle breedte van het onderwijs. Ontwerp, uitvoering en beheer van SIS berusten bij het ROA.

SIS bestaat uit een aantal verschillende schoolverlatersonderzoeken. In de eerste plaats bevat het de gegevens uit een enquête gericht op schoolverlaters van het voortgezet onderwijs (havo, vwo) en het voorbereidend beroepsonderwijs (vmbo), de VO-Monitor. Daarnaast vindt er een jaarlijks onderzoek plaats onder schoolverlaters van de beroepsopleidende (bol) en beroepsbegeleidende (bbl) leerwegen van het secundair beroepsonderwijs, de BVE-Monitor. In de derde plaats zijn opgenomen de gegevens uit de HBO-Monitor, die wordt gehouden onder afgestudeerden van het hbo. Deze schoolverlatersonderzoeken zijn gebaseerd op de zogeheten $T+1,5$ metingen, de schoolverlaters worden ongeveer anderhalf jaar na afstuderen bevraagd.

Onderwijsinstellingen kunnen met hun gediplomeerden deelnemen aan een van de monitoren. Bij de VO-monitor en de BVE-monitor kan een instelling ervoor kiezen om of zelf de adresgegevens aan te leveren of om hun gediplomeerden te laten benaderen via de adresbestanden van DUO. Vanaf meetjaar 2004 worden er door gebruikmaking 
van de onderwijsbestanden van DUO steekproeven getrokken..$^{18}$ Voor 2004 bestond de steekproef van de zowel de VO- als de BVE-monitor uit enkel de deelnemende scholen. Bij de HBO-Monitor is er geen sprake van steekproeven via DUO en bestaat de benaderde groep uit de gediplomeerden van de hogescholen die deelnemen aan de monitor.

In dit rapport ligt de focus op het leergedrag en de vroege loopbaan van schoolverlaters. Om de dataset hierbij te laten aansluiten voeren we een aantal selecties uit. Zo zetten we de maximumleeftijd voor mbo op 25 jaar en voor hbo op 30 jaar. Daarnaast nemen we alleen afgestudeerden mee die een voltijd studie hebben gevolgd. Verder selecteren we binnen hbo enkel op de afgestudeerden die een hbo bachelor hebben gevolgd, hbo master afgestudeerden worden buiten beschouwing gelaten. Tabel A.1 laat de resulterende samenstelling van de dataset zien. Doordat er binnen de BVE-monitor pas vanaf 2004 een steekproef getrokken wordt nemen we in het kader van representativiteit in dit rapport voor alle mbo-niveau enkel de data vanaf 2004 mee.

TABEL A.1 Samenstelling dataset SIS 2001-2017 naar opleidingsniveau

\begin{tabular}{|lllll|}
\hline Meetjaar & mbo 1 & mbo 2 en 3 & mbo 4 & hbo \\
\hline 2001 & - & - & - & 15801 \\
\hline 2002 & - & - & - & 13120 \\
\hline 2003 & - & - & - & 11029 \\
\hline 2004 & 201 & 2475 & 4167 & 12696 \\
\hline 2005 & 164 & 1985 & 4016 & 13450 \\
\hline 2006 & 157 & 1797 & 2693 & 13603 \\
\hline 2007 & 210 & 2405 & 3744 & 12458 \\
\hline 2008 & 289 & 3550 & 3667 & 14305 \\
\hline 2009 & 123 & 1765 & 2441 & 13108 \\
\hline 2010 & 189 & 2367 & 2608 & 14195 \\
\hline 2011 & 192 & 2304 & 2598 & 15486 \\
\hline 2012 & 117 & 1756 & 2266 & 14483 \\
\hline 2013 & 790 & 11072 & 12181 & 15783 \\
\hline 2014 & 129 & 1981 & 2452 & 16150 \\
\hline 2015 & 855 & 9957 & 11351 & 16640 \\
\hline 2016 & 1199 & 14299 & 15635 & 17675 \\
\hline 2017 & 932 & 11865 & 18515 \\
\hline
\end{tabular}

\section{Nameting SIS}

Binnen de schoolverlatersonderzoeken BVE-monitor en HBO-Monitor zijn alle respondenten gevraagd of zij willen deelnemen aan vervolgonderzoeken. Een selectie van de respondenten die hier ja op heeft geantwoord is vervolgens nog een keer benaderd.

18 Destijds bekend onder de naam IB-groep. 
Hbo

In oktober 2015 heeft er een vervolgonderzoek plaatsgevonden onder hbo-afgestudeerden die aan hebben gegeven benaderbaar te zijn voor vervolgonderzoek. Hierbij zijn de volgende afstudeercohorten meegenomen: 2007/2008, 2009/2010, 2010/2011 en 2011/2012. Omdat de nameting voor alle cohorten op hetzelfde moment heeft plaatsgevonden verschilt de tijd na afstuderen naar cohort. Voor het oudste cohort betekent dat deze nameting 8 jaar na afstuderen is plaatsgevonden en voor het jongste cohort vier jaar na afstuderen.

Doordat de adressen zelf zijn aangegeven door de respondenten en is sommige gevallen dit een aantal jaar geleden is zijn er een aantal e-mailadressen niet geldig gebleken. Van de 60.313 verzonden e-mails zijn er 56.386 ook daadwerkelijk aangekomen. Hiervan hebben 4364 de vragenlijst volledig ingevuld. In percentages is de totale respons dus $7,2 \%$ (compleet + incompleet).

\section{Mbo}

In oktober 2017 heeft er een vervolgonderzoek plaatsgevonden onder mbo-afgestudeerden die aan hebben gegeven benaderbaar te zijn voor vervolgonderzoek. Hierbij zijn de volgende afstudeercohorten meegenomen: 2004/2005, 2005/2006, 2006/2007, 2007/2008, 2008/2009, 2009/2010, 2010/2011, 2011/2012, 2012/2013 en 2013/2014. Omdat de nameting voor alle cohorten op hetzelfde moment heeft plaatsgevonden verschilt de tijd na afstuderen naar cohort. Voor het oudste cohort betekent dat deze nameting 12 jaar na afstuderen is plaatsgevonden en voor het jongste cohort drie jaar na afstuderen.

Doordat de adressen zelf zijn aangegeven door de respondenten en is sommige gevallen dit een aantal jaar geleden is zijn er een aantal e-mailadressen niet geldig gebleken. Van de 53.303 verzonden e-mails zijn er 46864 ook daadwerkelijk aangekomen. Hiervan hebben 6871 de vragenlijst volledig ingevuld. In percentages is de totale respons dus 21,9\% (compleet + incompleet). 



\section{BIJLAGE B}

\section{Verschillen tussen opleidingsrichtingen in conjunctuurgevoeligheid}

Opleidingen verschillen sterk met betrekking tot conjunctuurgevoeligheid. Voor sommige opleidingsrichtingen is er sprake van een vrij constante vraag naar recent afgestudeerden. Voor andere opleidingsrichtingen is echter sprake van wisselende vraag naar afgestudeerden, afhankelijk van de economische staat. Afgestudeerden van deze opleidingsrichtingen zullen het effect van de crisis sterker voelen. Er zullen in tijden van crisis duidelijk minder vacatures zijn en dus is het als pas afgestudeerden dan relatief lastig om een baan te vinden. Om deze conjunctuurgevoeligheid in kaart te brengen, maken we gebruik van een indicator uit het Arbeidsmarktinformatiesysteem van het ROA (AIS). Deze indicator wordt berekend door de sectorale werkgelegenheidsfluctuaties te relateren aan de mate waarin een opleidingsrichting in de verschillende bedrijfssectoren is vertegenwoordigd. ${ }^{9}$ In Tabel B.1 laten we de opleidingsrichtingen zien waarvoor de conjunctuurgevoeligheid als hoog of erg hoog getypeerd kan worden.

19 Hierbij wordt rekening gehouden met het feit dat de vraag naar sommige opleidingsrichtingen sterker fluctueert met de werkgelegenheidsschommelingen van de bedrijfssector dan de vraag naar andere opleidingsrichtingen. 
TABEL B.1 Opleidingstypes met een (erg) hoge conjunctuurgevoeligheid, 2017

\begin{tabular}{|lll|}
\hline Opleidingstype & Indicator & Typering \\
\hline mbo $2 / 3$ bouw en infra & 1,3 & erg hoog \\
\hline hbo informatica & 1,3 & erg hoog \\
\hline mbo 4 informatica & 1,25 & erg hoog \\
\hline hbo elektrotechniek & 1,23 & erg hoog \\
\hline hbo kunst & 1,16 & erg hoog \\
\hline mbo 4 media en vormgeving & 1,15 & erg hoog \\
\hline mbo 4 maatschappelijke zorg & 1,14 & erg hoog \\
\hline mbo 4 bouw en infra & 1,13 & hoog \\
\hline hbo journalistiek & 1,12 & hoog \\
\hline mbo 2/3 horeca & 1,11 & hoog \\
\hline mbo 4 technische installatie & 1,11 & hoog \\
\hline hbo werktuigbouwkunde & 1,11 & hoog \\
\hline mbo 2/3 informatica & 1,1 & hoog \\
\hline mbo 2/3 technische installatie & 1,1 & hoog \\
\hline mbo 2/3 maatschappelijke zorg & 1,09 & hoog \\
\hline mbo 4 horeca & 1,08 & hoog \\
\hline hbo bouwkunde en civiele techniek & 1,08 & hoog \\
\hline hbo chemie & 1,06 & hoog \\
\hline Bron: $A$ S & & \\
\hline
\end{tabular}

Bron: AIS ROA, 2017 


\section{BIJLAGE C}

\section{Robuuste schattingen van werkloosheidspercentages}

De in dit rapport gepresenteerde analyses maken gebruik van schattingen van het werkloosheidpercentage van schoolverlaters en afgestudeerden per onderzoekseenheid. De onderzoekseenheden bestaan uit landelijk gedefinieerde opleidingen per uitstroomjaar. Voor veel van de eenheden geldt dat we er per eenheid over weinig waarnemingen beschikken. Hierdoor kan worden aangenomen dat een ruw percentage in hoge mate aan meetfout onderhevig is. Om het storend effect hiervan te reduceren is gebruik gemaakt van multi-niveau analysemodellen. Multi-niveau modellen zijn hiërarchische modellen, waarbij individuele respondenten genest worden in eenheden op hogere aggregatieniveaus. Indien gewenst kunnen deze eenheden op hun beurt ook worden genest in eenheden op een nog hoger aggregatieniveau, die desnoods verder binnen nog grotere eenheden kunnen worden genest. Concreet worden voor dit onderzoek uitstroomjaren genest binnen opleidingen. De variantie in de oorspronkelijke kans op werk wordt dan opgedeeld in een overal percentage, een afwijking hiervan per opleiding, en daarbinnen een afwijking per uitstroomjaar.

Op elk niveau is de betrouwbaarheid van de geschatte waarde deels afhankelijk van het aantal observaties waarop de schatting is gebaseerd. Zo is het overall meerjarig werkloosheidspercentage van hbo-afgestudeerden erg betrouwbaar, omdat het gebaseerd is op alle schoolverlaters c.q. afgestudeerden van die in de loop der jaren aan het onderzoek hebben deelgenomen (om precies te zijn: afstudeerjaren 1999 t/m/2016). Op het niveau van opleidingen dat daaronder valt is het aantal observaties per eenheid beduidend lager, maar nog altijd in de meeste gevallen redelijk hoog, vooral gezien het feit dat een groot aantal uitstroomjaren bij de schattingen wordt betrokken. Bij sommige opleidingen is echter toch sprake van een relatief klein aantal observaties. Hiermee wordt rekening gehouden bij het berekenen van de afwijkingen van het overal gemiddelde werkloosheidspercentage. Enigszins simplificerend kunnen deze afwijkingen worden gezien als een gewogen gemiddelde van de werkelijk gemiddelde afwijking en nul, waarbij het gewicht wordt gevormd door het aantal waarnemingen per opleiding. Hierdoor wordt het geschatte afwijking bij grotere opleidingen vooral bepaald door de werkelijk gemiddelde afwijking, terwijl bij kleinere opleidingen deze afwijking in absolute zin naar beneden worden bijgesteld. Hierdoor wordt voorkomen dat toevallige 
afwijkingen op basis van kleine aantallen even zwaar wegen als afwijking van dezelfde omvang op basis van grotere aantallen.

Binnen iedere opleiding wordt vervolgens de gemiddelde afwijking per uitstroomjaar berekend. Zoals men zou verwachten, is het aantal waarnemingen per eenheid hierbij beduidend kleiner, waardoor de noodzaak tot correctie groter wordt. Het principe blijft echter hetzelfde: bij opleidingen met een relatief klein aantal waarnemingen per jaar, worden de afwijking per jaar van het overal gemiddelde voor de betreffende opleiding sterker afgezwakt dan bij opleidingen met vele waarnemingen elk jaar.

Het grootste voordeel van deze methode is dat het ons in staat stelt om tamelijk betrouwbare schattingen te maken, zelfs in het geval van relatief kleine aantallen. De methode maakt gebruik van de constatering dan er een landelijke markt is waarop alle opleidingen beconcurreren, en dat in het geval van kleine aantallen het aannemelijke is dat het werkelijk werkloosheidpercentage voor de betreffende opleiding in een bepaald jaar dichter bij het meerjarig gemiddelde van die opleiding ligt dan bij het meerjarig gemiddelde van het hbo als geheel. Er wordt dus informatie "geleend" van het gemiddelde van de betreffende opleiding om de schatting van het gemiddelde voor het betreffende uitstroomjaar betrouwbaarder te maken.

De schattingen zijn apart gemaakt voor bol, bbl en het hbo. Voor bol en bbl zijn tevens twee niveaus toegevoegd om extra precisie en betrouwbaarheid te geven. Ten eerst is er boven het niveau van opleidingen dat van niveau (bol/bbl 1-2-3-4) geplaatst. Dit is belangrijk omdat het ervoor zorgt dat het bekende niveauverschil tussen opleidingen voldoende wordt meegenomen. Verder wordt het uitstroomjaar eerst opgedeeld in paren jaren, waarbinnen vervolgens de afzonderlijke uitstroomjaren zijn genest. De reden hiervoor is een technische: in het mbo is in sommige jaren gebruik gemaakt van een steekproef, terwijl in andere jaren de hele populatie is benaderd. Dit betekent een veel groter aantal waarnemingen per opleidingen in sommige jaren dan in anderen. Wanneer we de nesting enkel per jaar doen, zouden in steekproefjaren schatting veel meer in de richting van het meerjarig gemiddelde worden getrokken, terwijl in populatiejaren het werkloosheidspercentage van de opleiding in het betreffend jaar veel bepalender zijn. Dit zou een ernstige verstoring van de ontwikkeling van de schattingen in de tijd tot gevolg kunnen hebben. Door eerst te nesten in paren jaren - waarvan één altijd een populatiejaar is - wordt de ontwikkeling in de tijd gepreserveerd.

Voor het hbo worden de schattingen per eenheid (opleiding $\mathrm{x}$ uitstroomjaar) als volgt opgebouwd:

1. het algemeen gemiddelde, d.w.z. het gemiddelde werkloosheidspercentage over alle hbo-respondenten van de betreffende periode (afstudeerjaren 1999 t/m/2016), plus:

2. de opleidingsspecifieke afwijking hierop, gewogen naar het aantal observaties per opleiding. 
Voor het mbo (bol en bbl) worden de schattingen per eenheid (niveau $\mathrm{x}$ opleiding $\mathrm{x}$ uitstroomjaar) als volgt opgebouwd:

1. het algemeen gemiddelde, d.w.z. het gemiddelde werkloosheidspercentage over alle hbo-respondenten van de betreffende periode (afstudeerjaren 1999 t/m/2016), plus:

2. de niveauspecifieke afwijking hierop, gewogen naar het aantal observaties per niveau, plus:

3. de afwijking hierop per paar uitstroomjaren, gewogen naar het aantal observaties per opleiding in ieder paar jaren, plus:

4. de afwijking hierop per individueel uitstroomjaar, gewogen naar het aantal observaties per opleiding in ieder uitstroomjaar.

Voor zowel het hbo als het mbo is binnen het laatste niveau nog altijd de individuele afwijking per schoolverlater/afgestudeerde, m.a.w. de werkelijke arbeidsmarktstatus van de betreffende schoolverlater/afgestudeerde. Deze informatie is echter niet te vergelijken tussen NSE en HBO-Monitor, en speelt derhalve geen verdere rol bij de analyses. 
